\title{
Conceptual Model of Uranium in the Vadose Zone for Acidic and Alkaline Wastes Discharged at the Hanford Site Central Plateau
}

\author{
MJ Truex \\ JE Szecsody \\ N Qafoku \\ JR Serne
}

September 2014

Pacific Northwest

NATIONAL LABORATORY

Proudly Operated by Battelle Since 1965 


\title{
DISCLAIMER
}

This report was prepared as an account of work sponsored by an agency of the United States Government. Neither the United States Government nor any agency thereof, nor Battelle Memorial Institute, nor any of their employees, makes any warranty, express or implied, or assumes any legal liability or responsibility for the accuracy, completeness, or usefulness of any information, apparatus, product, or process disclosed, or represents that its use would not infringe privately owned rights. Reference herein to any specific commercial product, process, or service by trade name, trademark, manufacturer, or otherwise does not necessarily constitute or imply its endorsement, recommendation, or favoring by the United States Government or any agency thereof, or Battelle Memorial Institute. The views and opinions of authors expressed herein do not necessarily state or reflect those of the United States Government or any agency thereof.

\author{
PACIFIC NORTHWEST NATIONAL LABORATORY \\ operated by \\ BATTELLE \\ for the \\ UNITED STATES DEPARTMENT OF ENERGY \\ under Contract DE-AC05-76RL01830
}

Printed in the United States of America
Available to DOE and DOE contractors from the Office of Scientific and Technical Information, P.O. Box 62, Oak Ridge, TN 37831-0062; ph: (865) 576-8401 fax: $(865) 576-5728$
email: reports $a$ adonis.osti.gov
Available to the public from the National Technical Information Service 5301 Shawnee Rd., Alexandria, VA 22312 ph: (800) 553-NTIS (6847) email: orders@ntis.gov <http://www.ntis.gov/about/form.aspx> Online ordering: http://www.ntis.gov




\section{Conceptual Model of Uranium in the Vadose Zone for Acidic and Alkaline Wastes Discharged at the Hanford Site Central Plateau}

MJ Truex

JE Szecsody

N Qafoku

JR Serne

September 2014

Prepared for

the U.S. Department of Energy

under Contract DE-AC05-76RL01830 


\section{Summary}

Historically, uranium was disposed of in waste solutions of varying waste chemistries at the Hanford Site Central Plateau. How uranium was distributed in the vadose zone during disposal, how it has continued to migrate through the vadose zone, and the magnitude of its potential impacts on groundwater are strongly influenced by geochemical reactions in the vadose zone. These geochemical reactions can be significantly influenced by the disposed-waste chemistry in the vadose zone near the disposal location. This report provides conceptual models and supporting information to describe uranium fate and transport in the vadose zone for both acidic and alkaline wastes discharged at a substantial number of waste sites in the Hanford Site Central Plateau. The conceptual models include consideration of how co-disposed acidic or alkaline fluids influence uranium mobility in terms of induced dissolution/precipitation reactions and changes in uranium sorption with a focus on the conditions near the disposal site. This information, when combined with the extensive information describing uranium fate and transport at near background $\mathrm{pH}$ conditions, enables focused characterization to support effective fate and transport estimates for uranium in the subsurface.

Mineral dissolution caused by acidic solutions can rapidly increase aqueous carbonate and phosphate concentrations in the pore water and result in a slower increase in silica and aluminum concentrations, likely released during clay dissolution. Most cation concentrations in the pore water also increase significantly, predominantly from dissolution, but also from ion exchange. Infiltration of a strong acid can release sediment-associated (e.g., native) uranium by causing sediment dissolution and by desorption. As acidic solutions are neutralized by interaction with the sediment, uranium precipitation as phosphates and carbonates can occur. Other aqueous ion concentrations also decrease at this time, likely as a result of quartz, diaspore, and dolomite precipitation. The acid buffering capacity and rate for Hanford sediments are mostly controlled by rapid carbonate dissolution and slow clay dissolution. In addition to dissolution and precipitation reactions, acidic waste solutions can decrease uranium sorption due to increases in pore-water ionic strength that are caused by sediment dissolution or the ionic strength of the disposed-waste solution.

Mineral dissolution can also be caused by alkaline solutions and result in moderate increases in the carbonate concentration in pore water, followed by a slower increase in silica concentration, likely from quartz, montmorillonite, muscovite, and kaolinite dissolution. Under these conditions, aqueous uranium concentration decreases rapidly through precipitation as Na-boltwoodite while the $\mathrm{pH}$ remains above 9.5. The neutralization rate and capacity for sediments in the Hanford Central Plateau is lower than the acid neutralization rate and capacity of these sediments. Therefore, dissolution reactions and resulting precipitation would occur to a greater depth with alkaline waste disposal than with acidic waste disposal under the same hydraulic conditions. Uranium sorption can be decreased by increases in pore-water ionic strength caused by sediment dissolution or the ionic strength of the disposed-waste solution (e.g., from sodium nitrate).

Waste-site information for the waste volume, $\mathrm{pH}$, and constituent concentrations (e.g., sodium nitrate) can be incorporated into the conceptual site model to estimate the impact on sorption and precipitation reactions. This evaluation provides a basis for interpreting characterization data from the site and refining the conceptual model for input to uranium transport assessments. Key conceptual model elements include the following items: 
- The spatial distribution of characterization data describing the mobile and immobile uranium present in borehole sediment samples (e.g., sediment analysis based on variable extraction procedures) can be evaluated with respect to the dissolution and precipitation processes anticipated from the waste chemistry and disposal volumes. The geochemical data can, at minimum, be applied to provide a technically defensible explanation for the presence of immobile uranium and support the associated modifications of uranium transport assessments and adjustments to the expected uranium mass discharge to groundwater. Key precipitates are uranium-carbonates and uranium-phosphates (especially for $\mathrm{pH}$ conditions near $\mathrm{pH}$ 5) for acidic waste sites and $\mathrm{Na}$-boltwoodite for alkaline waste sites.

- Waste-site information for the waste volume and waste acidity/alkalinity can be incorporated into the site conceptual model using sediment neutralization capacity and rate data to estimate the volumetric extent of the neutralization zone beneath the waste site and magnitude of the neutralization impact on geochemical conditions. This evaluation provides a basis for interpreting characterization data from the site and refining the conceptual model for input to uranium transport assessments.

- Waste-site pore-water chemistry data (e.g., ionic strength and dissolved constituent concentrations) can be interpreted to provide input to select appropriate geochemical and transport parameters for reactive transport calculations. Comparison of ionic strength and concentration of constituents, such as sodium, to background pore-water chemistry can be used to evaluate appropriate values for uranium sorption and, based on the spatial distribution of the pore-water chemistry, be used to refine the site conceptual model in terms of how transport would be expected to evolve over time as disposed wastes and pre-existing vadose zone pore-water mix. 


\section{Acknowledgments}

This document was prepared by the Deep Vadose Zone- Applied Field Research Initiative at Pacific Northwest National Laboratory. Funding for this work was provided by the U.S. Department of Energy (DOE) Richland Operations Office. The Pacific Northwest National Laboratory is operated by Battelle Memorial Institute for the DOE under Contract DE-AC05-76RL01830. 


\section{Acronyms and Abbreviations}

$\begin{array}{ll}1-\mathrm{D} & \text { one-dimensional } \\ 3-\mathrm{D} & \text { three-dimensional } \\ \mathrm{bgs} & \text { below ground surface } \\ \mathrm{Ci} & \text { curie(s) } \\ \mathrm{cm} & \text { centimeter(s) } \\ \mu \mathrm{eq} / \mathrm{g} & \text { microequivalent(s) per gram } \\ \mathrm{ft} & \text { foot (feet) } \\ \mathrm{ft}^{3} & \text { cubic foot (feet) } \\ \mu \mathrm{g} & \text { microgram(s) } \\ \mathrm{g} & \text { gram(s) } \\ \mathrm{gal} & \text { gallon(s) } \\ \mathrm{h} & \text { hour(s) } \\ \mathrm{in} . & \text { inch(es) } \\ \mathrm{kg} & \text { kilogram(s) } \\ \mathrm{L} & \text { liter(s) } \\ \mathrm{lb} & \text { pound(s) } \\ \mu \mathrm{mol} & \text { micromole(s) } \\ \mathrm{m} & \text { meter(s) } \\ \mathrm{M} & \text { molar } \\ \mathrm{mg} & \text { milligram(s) } \\ \mathrm{MTU} & \text { metric tons uranium } \\ \mathrm{pCi} & \text { picocurie(s) } \\ \mathrm{SIM} & \text { Soil Inventory Model } \\ \mathrm{yd} & \text { cubic yard(s) } \\ & \end{array}$




\section{Contents}

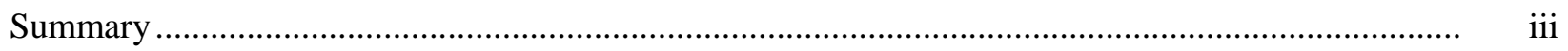

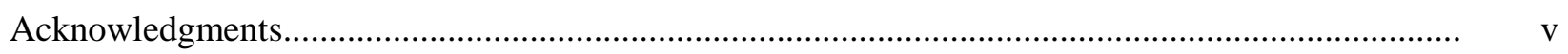

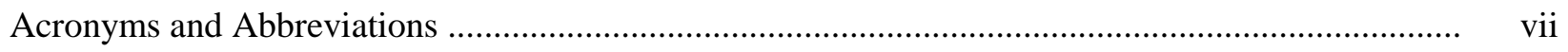

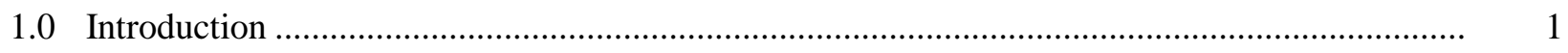

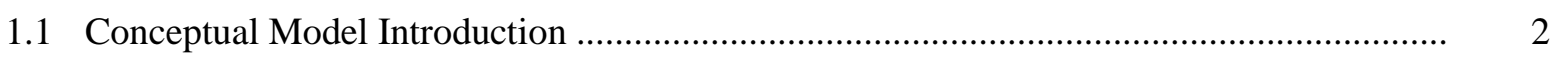

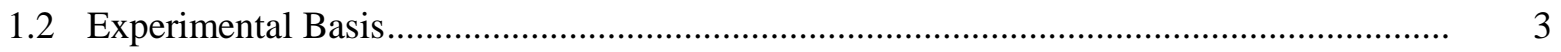



2.0 Summary of Acidic and Alkaline Waste Disposal Sites in the Hanford Central Plateau............ 5

3.0 Acidic Waste Site Conceptual Model .................................................................................. 15

3.1 Conceptual Model for Acidic Waste Sites ........................................................................ 15

3.2 Controlling Processes for Acidic Waste Sites ................................................................. 16

3.2.1 Acid Neutralization and Mineral Dissolution ..................................................... 16

3.2.2 Uranium and Non-Uranium Precipitates .......................................................... 17

3.2.3 Uranium Sorption and Transport................................................................. 18

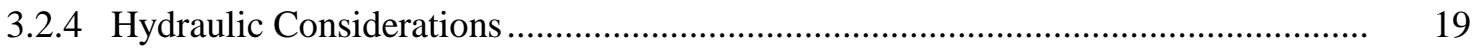

3.3 Recommended Characterization Approach for Acidic Waste Sites .................................. 19

3.3.1 Estimating Mobile Uranium Mass .................................................................... 20

3.3.2 Estimating Transport Parameters ….................................................................. 21

4.0 Alkaline Waste-Site Conceptual Model ............................................................................... 23

4.1 Conceptual Model for Alkaline Waste Sites ................................................................... 23

4.2 Controlling Processes for Alkaline Waste Sites ............................................................. 24

4.2.1 Alkaline Neutralization and Mineral Dissolution.................................................. 24

4.2.2 Uranium and Non-Uranium Precipitates .......................................................... 26

4.2.3 Uranium Sorption and Transport........................................................................ 26



4.3 Recommended Characterization Approach for Alkaline Waste Sites ............................... 27

4.3.1 Estimating Mobile Uranium Mass ..................................................................... 28

4.3.2 Estimating Transport Parameters ....................................................................... 29

5.0 Conclusions and Implications for Uranium Transport in the Hanford Vadose Zone .................. 31

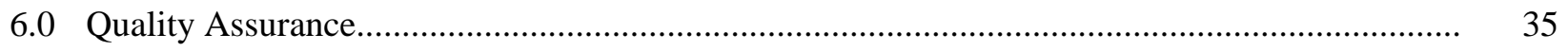

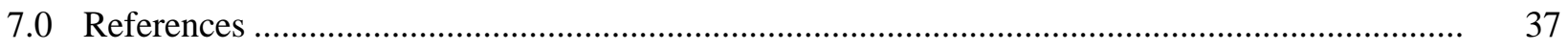

Appendix A - Sediment Mineralogy Information for the Hanford Central Plateau ........................... A. A 1 


\section{Figures}

1. Geochemical conceptual model showing dominant processes for acidic waste sites as summarized in Section 3.1 and described with additional details in Section 3.2.

2. Geochemical conceptual model showing dominant processes for alkaline waste sites as summarized in Section 4.1 and described with additional details in Section 4.2.

3. Sequential extraction of sediment samples beneath the U Tank Farm in the Hanford Central Plateau using the technique described in Section 1.2.

4. Composite geochemical model showing dominant processes for uranium at acidic and alkaline waste sites

\section{Tables}

1. Sequential extraction of uranium from sediment samples.

2. Description of acidic and alkaline uranium waste sites. 


\subsection{Introduction}

Historically, uranium was disposed in waste solutions of varying waste chemistry at the Hanford Central Plateau. The character of how uranium was distributed in the vadose zone during disposal, how it has continued to migrate through the vadose zone, and the magnitude of its potential impact on groundwater are strongly influenced by geochemical reactions in the vadose zone. These geochemical reactions can be significantly influenced by the chemistry of the disposed waste near the disposal location. Geochemical reactions, in addition to the physical processes limiting water flux through the vadose zone, are potential attenuation processes in the vadose zone for uranium and may limit the amount and flux of disposed uranium that reaches the groundwater (Truex and Carroll 2013). However, disposed-waste chemistry may also enhance uranium movement in the vadose zone (e.g., through reduced sorption). Thus, it is important to include consideration of how disposed-waste chemistry may affect uranium fate and transport in the vadose zone. Information from waste-chemistry evaluation can also be important for selecting borehole sample locations, identifying analyses diagnostic of uranium fate and transport, and interpreting characterization data in terms of future contaminant flux to groundwater. In summary, information about the impact of geochemical reactions on uranium fate and transport near the disposal facility, when combined with the extensive information describing uranium fate and transport at near background $\mathrm{pH}$ conditions (e.g., Zachara et al. 2007), enables focused characterization to support effective fate and transport estimates for uranium in the subsurface. In addition, geochemical reactions induced by disposed-waste chemistry can be analogous to geochemical conditions targeted by candidate remedies, and information from waste-chemistry evaluation and site characterization can help inform expected performance and endpoints (Lee et al. 2014) for these candidate remedies.

Although there were over 800 different chemical processes used at Hanford, a compilation of the major uranium discharges at Hanford (Simpson et al. 2006) shows that $81 \%$ of the uranium inventory is in 10 sites and $9.7 \%$ in the next 10 sites. Types of uranium discharged at waste sites can be grouped into four major categories (Zachara et al. 2007): 1) sites where cold start and fuel rod dissolution wastes were discharged, 2) sites where uranium nitrate hexahydrate waste was discharged with the waste having poorly defined $\mathrm{pH}, 3$ ) sites where highly acidic waste was discharged, and 4) sites where highly alkaline waste was discharged and containing inorganic complexants $\left(\mathrm{CO}_{3}, \mathrm{PO}_{4}\right)$. Significant organic complexants are projected for only a few sites. Uranium was typically disposed as uranyl ion (and may have formed complexes) in waste solutions different from the existing pore-water chemistry (e.g., $\mathrm{pH}$, carbonate, dissolved ions). Thus, geochemical reactions were induced to an extent that depended on the type and concentration of solutes and quantity of disposed fluids. These reactions need to be evaluated and considered in combination with the factors controlling water flux to evaluate uranium distribution at a waste site and predict the potential risk to groundwater. Common dominant anions present in disposed liquid wastes are nitrate (from nitric acid), sulfate (from sulfuric acid), and chloride (from hydrochloric acid). Common dominant cations present in disposed wastes include sodium (from $\mathrm{NaOH}$ added to neutralize $\mathrm{pH}$ ), potassium (from $\mathrm{KOH}$ and impurities in $\mathrm{NaOH}$ ), and aluminum. This report focuses on the large number of sites in the Hanford Central Plateau where either highly acidic or highly alkaline waste was disposed (see Section 2). 


\subsection{Conceptual Model Introduction}

Geochemical reactions impacting uranium solubility should be considered in terms of functionally reducing the mass that will reach the groundwater if the precipitate solubility is low and rates of contaminant release over time back into pore water are small enough that concentrations remain below a level that would cause a flux to groundwater that exceeds groundwater protection goals. Contributing factors to uranium solubility include oxidation state; carbonate, silica, or phosphate precipitates; presence of compounds that can form complexes with uranium; and the pore-water $\mathrm{pH}$. The pore-water $\mathrm{pH}$ and carbonate concentrations (and associated cation type and concentration) are particularly important for uranium mobility because at $\mathrm{pH} 8$ (typical Hanford Site sediment $\mathrm{pH}$ ), aqueous uranium is present as neutral and anionic carbonate species (i.e., $\left.\mathrm{Ca}_{2} \mathrm{UO}_{2}\left(\mathrm{CO}_{3}\right)_{3}, \mathrm{CaUO}_{2}\left(\mathrm{CO}_{3}\right)_{3}{ }^{2-}\right)$, whereas under highly alkaline conditions, aqueous uranium is present as anions $\left(\mathrm{CaUO}_{2}\left(\mathrm{CO}_{3}\right)_{3}{ }^{2-}, \mathrm{UO}_{2}\left(\mathrm{CO}_{3}\right)_{3}{ }^{4-}\right)$, and under acidic conditions, aqueous uranium is present as cations $\left(\mathrm{UO}_{2} \mathrm{OH}^{+}, \mathrm{UO}_{2}{ }^{2+}\right)$.

As a waste fluid reacts with sediments, a range of ions may be added to the pore water from mineral dissolution reactions and lead to formation of uranium precipitates or complexes that must be considered with respect to solid-phase uranium solubility and associated potential mobility. The type of ions produced from mineral dissolution is a function of the sediment mineralogy. The mineralogy of the Hanford sediments underneath the waste tanks is dominated by quartz (30-80\%) and plagioclase feldspar $(5-20 \%)$, with minor amounts $(<10 \%)$ of $\mathrm{K}$ feldspar and amphibole. The clay fraction $(<2 \mu \mathrm{m})$ is dominated by four clay minerals: illite (mica, 15-40 wt.\%), smectite (30-40 wt.\%), chlorite (15-20 wt.\%), and kaolinite (<10 wt.\%), with minor amounts of quartz, feldspar, and amphibole (5-10 wt. \%). Most of the Fe present in the sediments appears to be incorporated in the clay mineral structures: $\mathrm{Fe}$ (III) in smectite, $\mathrm{Fe}$ (II) in chlorite, and $\mathrm{Fe}$ (II) and $\mathrm{Fe}(\mathrm{III})$ in mica and possibly ferrogenous glass. Throughout the Hanford Central Plateau sediments of the same geologic formation and facies have a similar mineralogy. Additional information and associated references about sediment mineralogy for the Hanford Central Plateau are compiled in Appendix A.

The pore-water $\mathrm{pH}$ and other factors are important for uranium sorption. Sorption processes do not reduce the contaminant mass that will reach the groundwater, but delay transport and reduce contaminant concentrations in the vadose zone plume. Sorption is a function of contaminant properties, sediment properties, and pore-water chemistry (Zachara et al. 2007). Uranium sorption is also a function of complexation, and in natural waters $\mathrm{Ca}-\mathrm{U}-\mathrm{CO}_{3}$ aqueous complexes predominate with greater sorption at lower carbonate concentrations. Even without the formation of specific uranium complexes, additional ions from waste solutions may compete for sorption sites and impact uranium sorption.

There has been considerable study of uranium behavior in sediments decades after disposal in which the $\mathrm{pH}$ has been buffered and mineral dissolution and precipitation reactions have achieved equilibrium (Liu et al. 2008; McKinley et al. 2006; Ilton et al. 2006; Catalano et al. 2008; Um et al. 2009). However, there are only a few studies of uranium reactive transport in waste solutions. Tonkunuga et al. (2004) demonstrated that uranium migration from disposal of weakly acidic $(\mathrm{pH} 2)$ or alkaline $(\mathrm{pH} 11)$ wastes through sediments from Oak Ridge, Tennessee, and which have a considerable $\mathrm{pH}$ neutralization capacity, resulted in a nearly constant $\mathrm{pH}$ profile, minimal temporal or spatial geochemical changes, and uranium sorption that was predicted based on constant $\mathrm{pH}$ batch experiments. However, both strong acid $(\mathrm{pH}<1)$ or strong alkaline $(\mathrm{pH}>13)$ waste streams or large-volume weak acid or alkaline waste streams can exceed the sediment $\mathrm{pH}$ buffering capacity and result in an expanding zone of mineral dissolution and underlying zone of precipitation (Szecsody et al., 2013). In a study of high-volume alkaline (and salt) 
waste migration through Hanford sediments, a zone of silicate dissolution and down gradient precipitation zone was observed (Wan et al. 2004a, b). Geochemical impacts of alkaline tank waste on chromium fate and transport in the vadose zone have also been observed (Zachara et al. 2004).

\subsection{Experimental Basis}

The conceptual model descriptions in this report were developed based on results of recent laboratory experiments examining the geochemical processes that occur when Hanford sediments are exposed to uranium-laden acidic or alkaline wastes. Details of these experiments are provided by Szecsody et al. (2013) and Gartman et al. (2014). In summary, batch sediment-water experiments were conducted to quantify time scales of mineral dissolution in sediments and proton or $\mathrm{OH}$ - adsorption capacity. The sediment used for these experiments was a Hanford formation sediment collected at a $6.1 \mathrm{~m}$ depth in the Environmental Restoration Disposal Facility pit and it is similar to sand dominated Hanford formation sediments underneath the Hanford Central Plateau waste sites (Serne et al. 2008). These systems were studied for treatments in which the acid or base exceeded the sediment proton or $\mathrm{OH}$ - adsorption capacity (i.e., constant $\mathrm{pH}$ of 2 or 13), as well as for systems in which the acid or base added was less than the capacity (i.e., pH initially 2 or 13 and then neutralizing over time). Large (3-m-long) one-dimensional (1D) infiltration column experiments were then conducted to evaluate the integrated effects of dissolution/precipitation and changes in sorption on the migration of uranium through the sediment profile. These tests included conditions that caused zones where $\mathrm{pH}$ was neutralized and zones downgradient where the impact of pore-water ionic strength and precipitation reactions could be observed. Experiments were conducted over a sufficiently long time scale $(1200 \mathrm{~h})$ to evaluate changes in uranium precipitates. Separate infiltration column experiments were conducted for different injection solutions. Infiltration solutions included a baseline natural groundwater condition ( $\mathrm{pH} 8$ ), a weak acidic solution ( $0.01 \mathrm{M} \mathrm{HNO}_{3}$ ), a weak alkaline solution ( $0.1 \mathrm{M}$ sodium hydroxide+ $1.0 \mathrm{M}$ sodium nitrate), and a strongly acidic solution $\left(4 \mathrm{M} \mathrm{HNO}_{3}\right)$. Mineral dissolution was evaluated by changes in ion concentrations over time, and the impact on uranium mobility was evaluated by changes in aqueous uranium concentration and solid-phase distribution. A sequential extraction technique (Szecsody et al. 2010a, b, 2012, 2013) was applied to provide a functional evaluation of uranium distribution within fractions of different mobility in the subsurface (Table 1).

In addition, a series of macroscopic batch experiments combined with a variety of microscopic inspections and spectroscopic measurements were conducted to 1) determine uranium (U(VI)) sorption extent in the Hanford sediments for acidic $(\mathrm{pH} 2$ and $\mathrm{pH} 5)$ and neutral $(\mathrm{pH} 8)$ conditions in the presence of varying concentrations of sodium nitrate, a common co-disposed constituent, and 2) evaluate $U$ valence state and phase identity at the micron scale. The extent of uranium sorption to the Hanford sediment at three predetermined $\mathrm{pH}$ values $\left(\mathrm{pH}=2,5\right.$ and 8), five ionic strengths (the background $\mathrm{NaNO}_{3}$ concentrations were $0.1,0.5,1,5$ and $8 \mathrm{~mol} / \mathrm{L})$, and five uranium concentrations $(0.1,0.2,0.5,1$ and 10 $\mathrm{mg} / \mathrm{L})$, under both atmospheric conditions $(\mathrm{pH}=2,5$, and 8$)$ and controlled atmospheric conditions with undetectable amounts of $\mathrm{O}_{2}$ and $\mathrm{CO}_{2}(\mathrm{pH}=2$ and 5). The sediments were equilibrated for a relatively long time (weeks to months) with acid solutions to achieve a stable acidic $\mathrm{pH}$ of $\mathrm{pH} 2$ or $\mathrm{pH} 5$ before exposing them to the U(VI)-rich solutions. Pre- and post-test sediment characterization included Mössbauer and laser spectroscopy, microscale inspections with $\mu$-XRF (x-ray fluorescence), and molecular scale interrogations with XANES (x-ray absorption near edge structure) spectroscopy. 
Table 1. Sequential extraction of uranium from sediment samples.

\begin{tabular}{|c|c|c|c|}
\hline Extraction Solution & $\begin{array}{l}\text { Hypothesized Targeted } \\
\text { Sediment Components }\end{array}$ & $\begin{array}{l}\text { Interpreted Uranium Mobility } \\
\text { of Extracted Fraction }\end{array}$ & $\begin{array}{l}\text { Color } \\
\text { Code }\end{array}$ \\
\hline $\begin{array}{l}\text { 1. Aqueous: } \\
\text { uncontaminated } \\
\text { Hanford } \\
\text { groundwater }\end{array}$ & $\begin{array}{l}\text { Uranium in pore water and } \\
\text { a portion of sorbed uranium }\end{array}$ & Mobile phase & \\
\hline $\begin{array}{l}\text { 2. Ion Exch.: } \\
1 \mathrm{M} \mathrm{Mg-nitrate}\end{array}$ & Readily desorbed uranium & $\begin{array}{l}\text { Readily mobile through } \\
\text { equilibrium partitioning }\end{array}$ & \\
\hline $\begin{array}{l}\text { 3. Acetate } \mathrm{pH} 5: 1 \text { hour } \\
\text { in } \mathrm{pH} 5 \text { sodium } \\
\text { acetate solution }\end{array}$ & $\begin{array}{l}\text { Uranium associated with } \\
\text { surface exposed carbonate } \\
\text { precipitates, including } \\
\text { uranium-carbonates, or } \\
\text { other readily dissolved } \\
\text { precipitates }\end{array}$ & $\begin{array}{l}\text { Moderately mobile through } \\
\text { rapid dissolution processes }\end{array}$ & \\
\hline $\begin{array}{l}\text { 4. Acetate } \mathrm{pH} 2.3 \text { : } \\
1 \text { week in } \mathrm{pH} 2.3 \\
\text { acetic acid }\end{array}$ & $\begin{array}{l}\text { Dissolution of most } \\
\text { carbonate compounds, } \\
\text { including uranium- } \\
\text { carbonates, and sodium } \\
\text { boltwoodite }\end{array}$ & $\begin{array}{l}\text { Slow dissolution processes for } \\
\text { uranium release from this } \\
\text { fraction; mobility is low with } \\
\text { respect to impacting } \\
\text { groundwater }\end{array}$ & \\
\hline $\begin{array}{l}\text { 5. } 8 \mathrm{M} \mathrm{HNO}_{3}: 2 \text { hours } \\
\text { in } 8 \mathrm{M} \text { nitric acid at } \\
95^{\circ} \mathrm{C}\end{array}$ & $\begin{array}{l}\text { Considered to represent } \\
\text { total uranium extraction for } \\
\text { this study }\end{array}$ & $\begin{array}{l}\text { Very slow dissolution } \\
\text { processes are associated with } \\
\text { uranium release; functionally } \\
\text { immobile }\end{array}$ & \\
\hline
\end{tabular}

\subsection{Report Organization}

Currently, a significant amount of the disposed uranium inventory still resides in the deep (70- to 100m) vadose zone in the Hanford Central Plateau. Understanding the spatial and temporal evolution of geochemical processes that control migration of uranium in acidic and alkaline waste can be applied to predict the stability and mobility of uranium in the vadose zone. This report provides a general conceptual model for uranium behavior at sites where either acidic or alkaline waste was disposed. This conceptual model can be made site-specific by incorporating the relevant site conditions and characterization information for a site. The conceptual model is also intended to guide future site investigations and fate and transport interpretations for uranium in the vadose zone, especially with respect to estimating the future flux of uranium from the vadose zone into the groundwater.

Section 2.0 is a summary of known acidic and alkaline waste disposal sites in the Hanford Central Plateau. The acidic site conceptual model is described in Section 3.0. The alkaline site conceptual model is described in Section 4.0. For each type of disposal site, these sections present the overall conceptual model followed by a discussion of the key controlling processes. Recommended characterization targets and lines of evidence to support a site-specific conceptual model and evaluation of uranium mobility are also provided. Conclusions and implications for uranium transport in the Hanford vadose zone are provided in Section 5.0. 


\subsection{Summary of Acidic and Alkaline Waste Disposal Sites in the Hanford Central Plateau}

Hanford Central Plateau uranium waste disposal sites were reviewed with identification of those with a disposal inventory above about $500 \mathrm{~kg}$ and where the waste stream was acidic or alkaline (or a portion of the waste stream was acidic or alkaline) (Table 2). These sites, and potentially others, are candidates for application of the conceptual model considerations included in this report. Hanford Tank Farms were not included in this waste-site evaluation.

Table 2. Description of acidic and alkaline uranium waste sites.

\begin{tabular}{|c|c|}
\hline Site & Description \\
\hline $216-\mathrm{A}-19$ & Waste Stream(s): The site received PUREX startup waste during November and December \\
\hline \multirow[t]{13}{*}{ Crib } & 1955. Although several references state it also received condenser cooling water from the \\
\hline & 241-A-431 Building via the 216-A-34 Ditch, drawings do not show the 216-A-34 Ditch \\
\hline & connecting to the $216-\mathrm{A}-19$ Crib. While the U inventory ( 43 metric tons uranium [MTU]) \\
\hline & is the largest discharged to any Hanford liquid disposal waste site, all but $31 \mathrm{~kg} \mathrm{U}$ is \\
\hline & $\begin{array}{l}\text { estimated to have been discharged as solids (Soil Inventory Model [SIM, Corbin et al. } \\
\text { 2005: Kincaid et al. 2006]). }\end{array}$ \\
\hline & \\
\hline & Cumulative discharge inventory summary (SIM) is as follows: \\
\hline & - U: 43,444 kg (depleted) \\
\hline & - Na: $27,671 \mathrm{~kg}$ \\
\hline & - Fe: $18,345 \mathrm{~kg}$ \\
\hline & $\begin{array}{l}\text { - } \mathrm{NO}_{3}: 10,919 \mathrm{~kg} \\
\text { - } \mathrm{CO}_{3}: 5102 \mathrm{~kg}\end{array}$ \\
\hline & \\
\hline & $\begin{array}{l}\text { - } \mathrm{SO}_{4}: 4604 \mathrm{~kg} \\
\text { - } \mathrm{Cs}-137: 0 .\end{array}$ \\
\hline
\end{tabular}

Description: The crib is a $7.6 \times 7.6 \times 4.6 \mathrm{~m}$ deep $(25 \times 25 \times 15 \mathrm{ft}$ deep) excavation with no liquid dispersion structure.

Characterization: Only characterization data are from the $\mathrm{C} 3245$ borehole drilled through the borehole in April 2003. Borehole logging indicates uranium at $20-80 \mathrm{pCi} / \mathrm{g}$ located from 3.0-9.4 m (10-31 ft) bgs. Maximum Cs-137 activity level observed was $560 \mathrm{pCi} / \mathrm{g}$ at $2.4 \mathrm{~m}(8 \mathrm{ft})$ bgs. Sediment sampling showed $51 \mathrm{pCi} / \mathrm{g} \mathrm{U}-238$ (max) at $4.4 \mathrm{~m}(14.5 \mathrm{ft}) \mathrm{bgs}$. 
Table 2. (contd)

\begin{tabular}{ll}
\hline Site & Description \\
\hline 216-U-1\&2 & Waste Stream(s): The cribs received overflow from the 241-U-361 Settling Tank, which \\
Cribs & $\begin{array}{l}\text { received cell drainage from the 5-6 tank in 221-U and waste from the 224-U Building until } \\
\text { the uranium recovery process operations shut down in 1957. From July 1957 through May }\end{array}$ \\
& $\begin{array}{l}\text { 1967, the 216-U-1\&2 Cribs received waste from the 224-U Facility and equipment } \\
\text { decontamination waste and reclamation waste from the 221-U Canyon. }\end{array}$
\end{tabular}

The waste was low in salt and neutral to basic, except for the highly acidic discharge late in its history. Cumulative discharge inventory summary (SIM) is as follows:

- $\quad \mathrm{U}: 3955 \mathrm{~kg}$

- $\mathrm{C}-137: 1.8 \mathrm{Ci}$

- $\mathrm{Na}: 8467 \mathrm{~kg}$

- $\mathrm{K}: 127,476 \mathrm{~kg}$

- $\mathrm{NO}_{3}: 1,669,917 \mathrm{~kg}$

- $\mathrm{CO}_{3}: 6536 \mathrm{~kg}$

- $\mathrm{PO}_{4}: 6633 \mathrm{~kg}$

- $\mathrm{SO}_{4}: 171,222 \mathrm{~kg}$.

Description: The cribs include two wooden liquid dispersion structures in adjacent excavations $27.1 \times 8.5 \times 4.9 \mathrm{~m}$ deep $(89 \times 28 \times 16 \mathrm{ft}$ deep) that operated in series.

Characterization Data: Characterization borehole 299-W19-96 (A9797) was drilled through the 216-U-1 Crib in 1995. The highest zone of contamination was found at a depth of 6 to $12 \mathrm{~m}$ (20 to $40 \mathrm{ft}$ ). Maximum contamination levels in this zone included 2,400,000 pCi/g Sr-90, 1,430,000 pCi/g Cs-137 and 438 pCi/g Pu-239/240.

Three additional characterization boreholes (299-W19-95, 299-W19-96 and 299-W19-97) were drilled near the 216-U-1\&2 Cribs in 1995. Borehole sediment samples and surface soil samples were collected and analyzed. Uranium contaminated perched water was observed in the Cold Creek Unit (CCU).

Shallow push holes surround the crib at various distances. Isopleth maps of uranium and Cs-137 contamination indicate significant lateral contamination spread.

There are thought to be two zones of uranium concentration —one that is shallow and another in the deeper Cold Creek silt and carbonate layer.

Unusual Occurrence 85-17: Unusual Occurrence 85-17 reports groundwater samples taken in January 1985 from wells 299-W19-03 and 299-W19-11 indicating 60,000 and 85,000 $\mathrm{pCi} / \mathrm{L}$ of uranium. Previous routine samples averaged less than $500 \mathrm{pCi} / \mathrm{L}$. Investigation revealed that liquid waste from the $216-\mathrm{U}-16 \mathrm{Crib}$, located south of the $216-\mathrm{U}-1 \& 2$ Cribs, had migrated north along a subsurface caliche layer. Existing groundwater monitoring wells around the 216-U-1\&2 Cribs provided a pathway for the contamination to reach the groundwater. 
Table 2. (contd)

\begin{tabular}{|c|c|}
\hline Site & Description \\
\hline $216-\mathrm{U}-8$ & $\begin{array}{l}\text { Waste Stream(s): The cribs received acidic process condensate from the } 221-\mathrm{U} \text { and } 224-\mathrm{U} \\
\text { Buildings along with drainage from the } 291-\mathrm{U} \text { stack via an underground vitrified clay } \\
\text { pipeline. }\end{array}$ \\
\hline
\end{tabular}

The waste was acidic. Discharge inventory summary (SIM) is as follows:

- $\mathrm{U}: 25,512 \mathrm{~kg}$

- Tc-99: $2.7 \mathrm{Ci}$

- C-137: $0.05 \mathrm{Ci}$

- $\mathrm{Am}-241: 4.7 \mathrm{Ci}$

- $\quad \mathrm{Na}: 7482 \mathrm{~kg}$

- $\mathrm{K}: 3,624,455 \mathrm{~kg}$

- Ca: $5852 \mathrm{~kg}$

- $\mathrm{NO}_{3}: 4,556,685 \mathrm{~kg}$

- $\mathrm{PO}_{4}: 79,023 \mathrm{~kg}$

- $F: 7295 \mathrm{~kg}$

- $\mathrm{Cl}: 8192 \mathrm{~kg}$.

Description: The site consists of three wood timber liquid dispersion structures set in series within a $48.8 \times 15.2 \times 9.7 \mathrm{~m}$ deep $(160 \times 50 \times 32 \mathrm{ft}$ deep $)$ excavation. Each structure is 4.9 by 4.9 by $3.0 \mathrm{~m}$ deep ( 16 by 16 by $10 \mathrm{ft})$. The structures were filled with $1.3-\mathrm{cm}(0.5$-in.) crushed stone. There is roughly $2,070 \mathrm{~m}^{3}\left(73,000 \mathrm{ft}^{3}\right)$ of gravel fill in the cribs.

Characterization: During the 1995 Limited Field Investigation, borehole (299-W19-94)

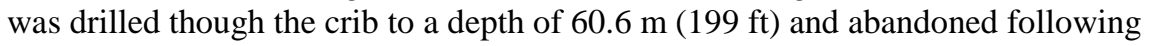
characterization. Gamma logging detected U-238 (831 pCi/g @ 11.4 m [37.5 ft] bgs and $150 \mathrm{pCi} / \mathrm{g} @ 56.4 \mathrm{~m}[185 \mathrm{ft}] \mathrm{bgs})$ in the borehole. Soil samples showed high concentrations of Cs-137 and Sr-90 near the underground vitrified clay pipeline.

Isopleth maps of uranium, Tc-99, and Cs-137 contamination obtained from boreholes drilled to approximately $45 \mathrm{ft}$ deep during 2005 indicate significant contamination lateral spread. 
Table 2. (contd)

\begin{tabular}{ll}
\hline Site & Description \\
\hline 216-U-12 & Waste Stream(s): From April 1960 to May 1967, the site received 291-U-1 Stack drainage, \\
& 241-WR Vault waste and 224-U process condensate via the C-5 Tank. Contaminated water \\
& from the 241-WR Vault was discharged to the crib in October 1965 that included 3.14 \\
& kilograms (6.9 lb) of thorium. From May 1967 to September 1972, the site received the \\
& above wastes (excluding the 241-WR Vault waste) and occasional waste via the C-7 Tank \\
& in the 224-U Building. From September 1972 to November 1981, the site was inactive. \\
& From November 1981 to January 1987, the site received acidic process condensate (typical \\
& pH range was 0.5-1.5) from the 224-U Building. The crib also received miscellaneous \\
storm drain wastes from 224-U Building. Between April 1960 and September 1972, & 6.7E+5 kg nitrate was released to the crib from the uranium tri-oxide process.
\end{tabular}

The waste was acidic. Cumulative discharge inventory summary (SIM) is as follows:

- $\mathrm{U}: 6458 \mathrm{~kg}$

- Tc-99: $0.7 \mathrm{Ci}$

- Cs-137: 69.6 Ci

- Am-241: $1.4 \mathrm{Ci}$

- Na: $3921 \mathrm{~kg}$

- $\mathrm{K}: 1,834,294 \mathrm{~kg}$

- Ca: $2965 \mathrm{~kg}$

- $\mathrm{NO}_{3}: 2,279,820 \mathrm{~kg}$

- $\mathrm{PO}_{4}: 40,049 \mathrm{~kg}$

- F: $3707 \mathrm{~kg}$

- $\mathrm{Cl}: 8192 \mathrm{~kg}$

Description: The 216-U-12 Crib includes a below-grade $30 \mathrm{~cm}$ (12 in.) diameter vitrified clay pipe running horizontally the length of the crib within a $30.5 \times 3.0 \times 4.6 \mathrm{~m}$ deep $(100 \mathrm{x}$ 10 x $15 \mathrm{ft}$ deep) excavation that was filled with $264 \mathrm{~m}^{3}$ gravel.

Characterization: Limited characterization data are available from a 1994 borehole placed adjacent to the crib footprint, which showed no contaminants above background. Spectral gamma borehole logging of a borehole through the crib to $53 \mathrm{~m}(175 \mathrm{ft}) \mathrm{bgs}$ indicates Cs- 137 from 5 to $18 \mathrm{~m}$ (16 to $59 \mathrm{ft}$ ) (maximum activity of $16,100 \mathrm{pCi} / \mathrm{g}$ at $7 \mathrm{~m}[23 \mathrm{ft}]$ ) and

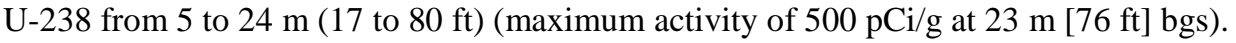

Isopleth maps of uranium and Cs-137 contamination obtained from boreholes drilled to approximately $40-50 \mathrm{ft}$ deep during 2005 indicate significant lateral contamination spread. 
Table 2. (contd)

\begin{tabular}{ll}
\hline Site & Description \\
\hline 216-B-12 & $\begin{array}{l}\text { Waste Stream(s): The crib originally received 221-U and 224-U condensate waste } \\
\text { transported from 200 West Area via the Cross Site Transfer Line (line V219). Later, the } \\
\text { crib received condensate waste from 221-B Plant. }\end{array}$
\end{tabular}

From November 1952 to December 1957, the site received the process condensate waste from the tributyl phosphate uranium recovery processes at the 221-U and 224-U Buildings as well as B Plant condensate. From December 1957 to May 1967, the site was inactive. From May 1967 to November 1967, the site received construction waste from 221-B Building. After November 1967, the site received process condensate from 221-B Building.

The waste was low in salt and neutral to basic. Cumulative discharge inventory summary (SIM) is as follows:

- U: $15,112 \mathrm{~kg}$

- Na: $14,051 \mathrm{~kg}$

- Ca: $8147 \mathrm{~kg}$

- $\mathrm{K}: 2,286,683 \mathrm{~kg}$

- $\mathrm{NO}_{3}: 2860,615 \mathrm{~kg}$

- $\mathrm{CO}_{3}: 11,676 \mathrm{~kg}$

- $\mathrm{PO}_{4}: 50,066 \mathrm{~kg}$

- $F: 4743 \mathrm{~kg}$

- Sr-90: $120 \mathrm{Ci}$

- Tc-99: $1.6 \mathrm{Ci}$

- Cs-137: $326 \mathrm{Ci}$

Description: The unit consists of a series of three cascading, 4.9 by 4.9 by $3.0-\mathrm{m}$ ( 16 by 16 by 10 -ft) high wooden boxes in a $48.8 \times 15.2 \times 9.1 \mathrm{~m}$ deep $(160 \times 50 \times 30 \mathrm{ft}$ deep) excavation. A $1.3-\mathrm{cm}(0.5$-in.) rock backfill lies in the bottom $3.7 \mathrm{~m}(12 \mathrm{ft})$ of the


contains $2,900 \mathrm{~m}^{3}\left(3,800 \mathrm{yd}^{3}\right)$ of $1.3-\mathrm{cm}(0.5$-in. $)$ gravel.

Characterization: Wells 299-E28-9, 299-E28-16, 299-E28-65, and 299-E28-66 monitor this unit. Data indicate breakthrough to groundwater has not occurred at this site.

Characterization borehole C3246, drilled into the crib in June 2003, was drilled to a depth of $308 \mathrm{ft}$. Geophysical logging found Cs-137, U-238 and Eu-154. The maximum concentration of Cs-137, 121,000 pCi/g, was found at $35 \mathrm{ft}$ bgs. Approximately $10 \mathrm{pCi} / \mathrm{g}$ $\mathrm{U}-238$ was observed at $36.0-36.6 \mathrm{~m}(118-120 \mathrm{ft}) \mathrm{bgs}$.

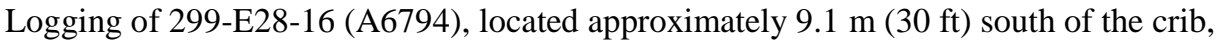
showed $\sim 100 \mathrm{pCi} / \mathrm{g} \mathrm{U}-238$ at $47 \mathrm{~m}(155 \mathrm{ft}) \mathrm{bgs}$. This hole also indicated $\sim 100,000 \mathrm{pCi} / \mathrm{g}$ Cs-137 at $30.5 \mathrm{~m}$ (100 ft) bgs, which may have masked U-238 presence.

Logging of 299-E28-65 (A6816), located in the crib, showed greater than 10,000 pCi/g Cs-137 from the bottom of the crib to $21 \mathrm{~m}(70 \mathrm{ft}) \mathrm{bgs}$, with a maximum of approximately $250,000 \mathrm{pCi} / \mathrm{g}$ at a depth corresponding to the bottom of the crib. 
Table 2. (contd)

\begin{tabular}{|c|c|}
\hline Site & Description \\
\hline $\begin{array}{l}241-\mathrm{BX}- \\
102 \text { overfill } \\
\text { event }\end{array}$ & $\begin{array}{l}\text { Waste Stream(s): In 1951, this tank was receiving the "metal waste" stream from the } \\
\text { bismuth phosphate plutonium separation process at B Plant. }\end{array}$ \\
\hline $\begin{array}{l}(\mathrm{UPR}-200- \\
\mathrm{E}-5)\end{array}$ & $\begin{array}{l}\text { On March 20, 1951, a cascade outlet became plugged, resulting in the BX-102 Tank } \\
\text { overfilling. Approximately } 348,000 \mathrm{~L} \text { ( } 91,600 \text { gal) of metal waste from the bismuth } \\
\text { phosphate process was released containing approximately } 10.1 \text { MTU. }\end{array}$ \\
\hline
\end{tabular}

Description: Contamination migrated beyond the 241-BX/BY fence, to the northeast and under the road north of the B Farm with increasing depth to the northeast. The waste apparently is partially perched on the Cold Creek fine-grained interval and has leaked through to the groundwater. A groundwater uranium plume is flowing to the northwest under the BY cribs.

Characterization: There is excellent characterization information available for various depths and locations of holes. Shallow push holes within the tank farm surround the release point. There are several deep boreholes next to the tank and eastward to the point of the projected release to groundwater.

The depth of the uranium in the vadose zone increases from the source location to the northeast. Contamination near the CCU is thought to represent the most severe vadose zone threat to groundwater from uranium on the site.

299-E33-45 (C3269) located west of the BX-102 tank but inside the tank farm fence revealed silt bands in the upper $51.8 \mathrm{~m}(170 \mathrm{ft})$ that exhibit uranium, sodium, nitrate, and technetium-99 contamination. Soil $\mathrm{pH}$ is elevated from 22.8 to $51.8 \mathrm{~m}$ (75 to $170 \mathrm{ft})$. $\underline{\mathrm{U}-}$ $\underline{238}$ was present between 21.9 and $60.3 \mathrm{~m} \mathrm{(72} \mathrm{and} 198 \mathrm{ft})$ with a peak value of $240 \mathrm{pCi} / \mathrm{g}$ at $41.5 \mathrm{~m}(136 \mathrm{ft})$. Tc-99 was noted from 36.6-70.1 m (120-230 ft) with a maximum of about $30 \mathrm{pCi} / \mathrm{g}$ (water extraction) at $51.8 \mathrm{~m}(170 \mathrm{ft})$.

Borehole 299-E33-343, located at the northwest corner of the B Tank Farm, appears to be near the position where uranium located in a perched water zone on the CCU is entering the aquifer. Based on data from this borehole and others, PNNL-19277 (Conceptual Models for Migration of Key Groundwater Risk Contaminants through the Vadose Zone and into the Upper Unconfined Aquifer Below the B Complex), estimates that only a small fraction of the mobile uranium associated with the BX-102 overfill event has reached the aquifer.

Boreholes 299-E33-18 (A4844) and 299-E33-345, located approximately $38 \mathrm{~m}$ (125 ft) east of 299-E33-343, also revealed high uranium contents in the CCU. 
Table 2. (contd)

\begin{tabular}{|c|c|}
\hline Site & Description \\
\hline $\begin{array}{l}216-A-3 \text {, } \\
\text { and }-9\end{array}$ & 216-A-3 Crib \\
\hline Cribs & $\begin{array}{l}\text { Waste Stream(s): Until November 1967, the site received wastes from the silica-gel } \\
\text { regeneration in the 203-A Building, the uranyl nitrate hexahydrate (UNH) storage pit } \\
\text { drainage, and the liquid waste from the 203-A Pump House. After November 1967, the } \\
\text { site received UNH Storage Pit drainage, liquid drainage, liquid waste from the 203-A } \\
\text { Building enclosure sumps, and the heating coil condensate from the P1 through P4 UNH } \\
\text { tanks. Between } 1967 \text { and 1970, the site discontinued receiving discharge from silica-gel } \\
\text { regeneration wastes. The waste included uranium, cesium-137, strontium-90 and } \\
\text { ruthenium-106. The site was taken out of service in Anril 1981. }\end{array}$ \\
\hline
\end{tabular}

Description: The unit contains a 10-cm- (4-in.-) diameter Schedule 10 perforated 304 stainless steel pipe placed horizontally $2.4 \mathrm{~m}(8 \mathrm{ft})$ below grade and two $6.1-\mathrm{m}(20-\mathrm{ft})$ lengths of this pipe placed perpendicularly to the first pipe, forming an $\mathrm{H}$ pattern in a $6.1 \mathrm{x}$ $6.1 \times 4.9 \mathrm{~m}$ deep $(20 \times 20 \times 16 \mathrm{ft}$ deep) excavation. The site has approximately $2.4 \mathrm{~m}(8 \mathrm{ft})$ of gravel fill with a volume of $280 \mathrm{~m}^{3}\left(10,000 \mathrm{ft}^{3}\right)$ and has been backfilled.

\section{6-A-9 Crib}

Waste Stream(s): Until February 1958, the site received acid fractionator condensate and condenser cooling water from the 202-A Building. In February 1958, the crib was judged to have reached its capacity and was taken out of service. In April 1966, the crib was approved for disposal of liquid $\mathrm{N}$ Reactor decontamination waste, which continued to October 1966. From October 1966 to August 1969, the site was inactive. In August 1969, the site again received acid fractionator condensate from the 202-A Building. The waste was acidic.

Description: The site contains a $25-\mathrm{cm}-(10-$ in.-) diameter Schedule 30 steel perforated

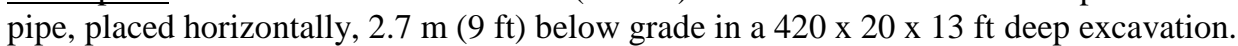
The site has $1,840 \mathrm{~m}^{3}\left(65,000 \mathrm{ft}^{3}\right)$ of gravel fill and has been backfilled.

Characterization: Groundwater wells 299-E24-3, E24-4, E24-5, and E24-63 monitor this unit. The data indicate that no breakthrough to groundwater has occurred at this site. 
Table 2. (contd)

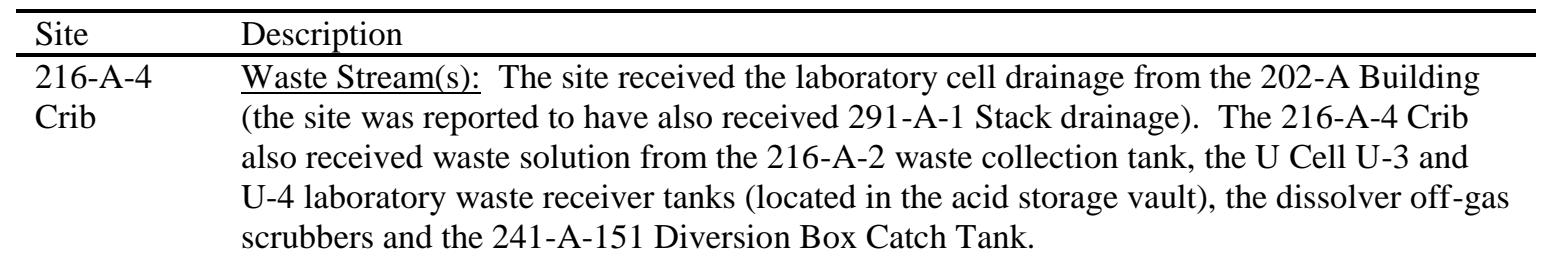

The waste was low in salt and neutral to basic. Cumulative discharge inventory summary (SIM) is as follows:

- $\mathrm{U}: 5388 \mathrm{~kg}$

- $\mathrm{K}: 75,974 \mathrm{~kg}$

- $\mathrm{NO}_{3}: 95,373 \mathrm{~kg}$

- $\mathrm{PO}_{4}: 1691 \mathrm{~kg}$

- Cs-137: 4.9 Ci

Description: Excavation was $20 \times 20$ x 26-ft deep. Two 6.1-m (20-ft) lengths of $15-\mathrm{cm}$ (6in.) perforated vitrified clay pipe form a horizontal cross pattern are located $5.5 \mathrm{~m}(18 \mathrm{ft})$


$\left(10,000 \mathrm{ft}^{3}\right)$ and has been backfilled.

Characterization: Characterization borehole C4560 was drilled into the crib in 2004. Drilling was suspended due to an unexpected extremely high zone of radiological

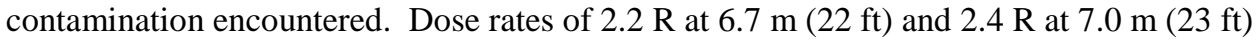
were observed.

Borehole C5301 (299-E24-23), drilled in late 2006/early 2007, was placed south of the southwest corner of the crib and drilled $109.7 \mathrm{~m}$ (360 ft) deep. Cs-137 was the only manmade isotope detected. 
Table 2. (contd)

\begin{tabular}{ll}
\hline Site & Description \\
\hline $216-\mathrm{S}-1 \& 2$ & Waste Stream(s): This unit was used as a subsurface liquid distribution system that \\
& received cell drainage and process condensate from the REDOX facility. The waste had a \\
& pH of 2.1. The waste was discharged to the cribs in batches with each batch being \\
& approximately 19,000 L (4940 gal), and an average of 10 batches were discharged each \\
& day. When the crib was abandoned, it had received approximately 750,000 Ci of mixed \\
& fission products.
\end{tabular}

The site received cell drainage from the D-1 Receiver Tank and process condensate from the D-2 Receiver Tank in the 202-S Building.

The waste was acidic. Cumulative discharge inventory summary (SIM) is as follows:

- U: $2220 \mathrm{~kg}$

- $\mathrm{Na}: 9778 \mathrm{~kg}$

- $\mathrm{NO}_{3}: 210,879 \mathrm{~kg}$

- Sr-90: $959 \mathrm{Ci}$

- Tc-99: $2.6 \mathrm{Ci}$

- Cs-137: $827 \mathrm{Ci}$

Description: The excavation includes two open-bottomed crib boxes, each measuring $3.7 \mathrm{x}$ $3.7 \mathrm{~m}(12 \mathrm{ft} \times 12 \mathrm{ft})$, made of timbers, and placed in a 3.0-m- (10-ft-) thick gravel bed in a $27.4 \times 12.2 \times 10.4 \mathrm{~m}$ deep $(90 \times 40 \times 34-\mathrm{ft}$ deep $)$ excavation. The cribs are connected in series where overflow from the crib box S1 flows into crib box S2 via an underground pipe.

Characterization: Core samples from wells drilled in 1956 determined that Cs-137 was contained in the upper strata beneath the cribs, but that $\mathrm{Sr}-90$ had reached groundwater. Core samples from five additional wells drilled in the vicinity of the 216-S-1 \& -2 Cribs in 1966 indicated that 90 percent of the Cs-137 and less than 10 percent of the Sr-90 was

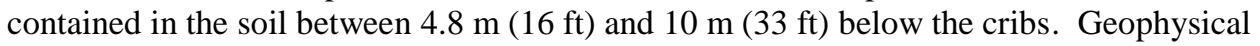
logging performed in 1984 indicated that Cs-137 concentrations were highest just below the bottom of the crib and decreased rapidly with depth. There has been little change in the gamma activity profiles since 1958 . 
Table 2. (contd)

\begin{tabular}{|c|c|}
\hline Site & Description \\
\hline \multirow[t]{5}{*}{$216-S-7$} & $\begin{array}{l}\text { Waste Stream(s): From January } 12,1956 \text {, to April } 12,1959 \text {, the unit received REDOX cell } \\
\text { drainage from the D-1 Receiver Tank, process condensate from the D-2 Receiver Tank, } \\
\text { and condensate from the H-6 Condenser in } 202-S \text { Building. A buildup of beta activity in } \\
\text { this crib prompted the rerouting of H- } 6 \text { waste material to the underground waste storage } \\
\text { tanks. The crib continued to receive waste from D-1 and D-2 Vessels until July } 1965 \text {. }\end{array}$ \\
\hline & $\begin{array}{l}\text { The waste was acidic. Cumulative discharge inventory summary (SIM) is as follows: } \\
\text { - } \mathrm{U}: 3411 \mathrm{~kg} \\
\text { - } \mathrm{Na}: 11,760 \mathrm{~kg} \\
\text { - } \mathrm{NO}_{3}: 432,149 \\
\text { - } \mathrm{Sr}-90: 1471 \mathrm{Ci} \\
\text { - } \mathrm{Tc}-99: 2.5 \mathrm{Ci} \\
\text { - } \mathrm{Cs}-137: 979 \mathrm{Ci} \\
\text { - } \mathrm{Pu}-239 / 240: 83.7 \mathrm{Ci}\end{array}$ \\
\hline & $\begin{array}{l}\text { Description: The unit consists of two wooden structures measuring } 4.9 \mathrm{~m}(16.1 \mathrm{ft}) \text { square } \\
\text { and } 1.6 \mathrm{~m}(5.2 \mathrm{ft}) \text { high. The structures are set } 15.2 \mathrm{~m}(50 \mathrm{ft}) \text { apart, center to center, in a } \\
30.5 \times 15.2 \times 6.7 \mathrm{~m} \text { deep }(100 \times 50 \times 22 \mathrm{ft} \text { deep }) \text { excavation. The structures were set in } \\
\text { gravel and covered with backfill. The two structures are connected in parallel by a pipe, } \\
\text { allowing the flow to be equally distributed to both cribs. }\end{array}$ \\
\hline & $\begin{array}{l}\text { Characterization: Characterization borehole } \mathrm{C} 4557 \text { was installed in late } 2004 \text { and } \\
\text { completed in early } 2005 \text {. Geophysical logging indicated maximum Cs- } 137 \text { of two million } \\
\text { pCi/g at } 7.8 \mathrm{~m}(25 \mathrm{ft}) \text { bgs. No other manmade radionuclides were detected. }\end{array}$ \\
\hline & $\begin{array}{l}\text { SGLS characterization of } 299-\mathrm{W} 22-33 \text {, located in the crib footprint, indicated } 300 \mathrm{pCi} / \mathrm{g} \\
\text { Cs-137 at } 8.4 \mathrm{~m}(27.5 \mathrm{ft}) \text {. No other manmade radionuclides were detected. }\end{array}$ \\
\hline
\end{tabular}




\subsection{Acidic Waste Site Conceptual Model}

A general conceptual model for uranium at waste sites where acidic wastes were disposed is described in this section for use as a template in developing a site-specific conceptual model. Primary experimental support for the conceptual model is described by Szecsody et al. (2013) and Gartman et al. (2014). The conceptual model incorporates the impacts of acid neutralization on uranium transport as influenced by uranium and non-uranium bearing mineral dissolution/precipitation and changes in uranium aqueous species partitioning (i.e., sorption) that are imposed by this mineral dissolution/precipitation and the waste fluid constituents. The impacts of other waste constituents (e.g., complexants) would need to be considered in addition to the processes discussed in this section.

\subsection{Conceptual Model for Acidic Waste Sites}

Uranium fate and transport in the vadose zone beneath acidic waste sites are impacted by the following processes. Mineral dissolution caused by acidic solutions can increase aqueous carbonate and phosphate concentrations in the pore water and result in a slower increase in dissolved silica and aluminum concentrations, likely released during clay dissolution. Most cation concentrations in the pore water also increase significantly, predominantly from mineral dissolution, but also from ion exchange. Infiltration of a strong acid can release sediment-associated (e.g., native) uranium by causing sediment dissolution. The extent to which mineral dissolution occurs at acidic waste disposal sites depends on the concentration and mass of acid relative to the sediment proton adsorption capacity. As acidic solutions are neutralized by interaction with the sediment, uranium precipitation as phosphates and carbonates can occur. Other aqueous ion concentrations also decrease at this time, likely from quartz, diaspore, and dolomite precipitation. The acid buffering capacity and rate for Hanford sediments is mostly controlled by rapid carbonate dissolution and slow clay dissolution. In addition to dissolution and precipitation reactions, the addition of acidic waste solutions can decrease uranium sorption due to increases in porewater ionic strength that are caused by sediment dissolution or from the ionic strength of the disposedwaste solution. Figure 1 depicts the conceptual model for dominant geochemical processes impacting uranium fate and transport beneath acidic waste sites. This conceptual model must also incorporate consideration of water and waste volume discharged and hydraulic transport conditions (not shown). Additional discussion of controlling geochemical processes and relevant mineralogy are described in the following sections. A recommended characterization approach for acidic waste sites is then provided. 


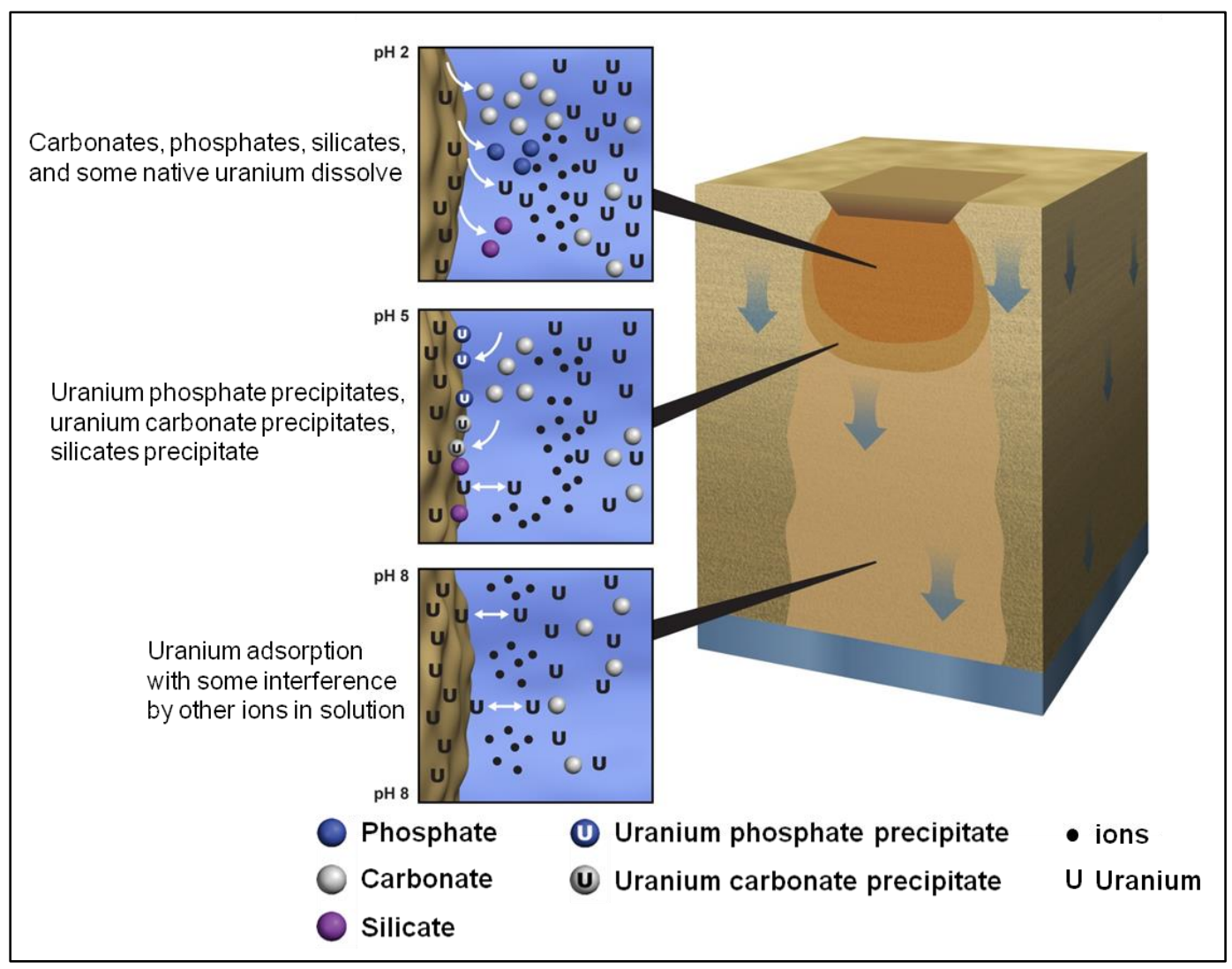

Figure 1. Geochemical conceptual model showing dominant processes for acidic waste sites as summarized in Section 3.1 and described with additional details in Section 3.2.

\subsection{Controlling Processes for Acidic Waste Sites}

Contact of acidic waste with sediments induces acid neutralization reactions which, in the Hanford Central Plateau, are initially dominated by carbonate dissolution. However, other minerals are also dissolved with extended contact time and/or as carbonates become depleted. Mineral dissolution leads to increased ion concentrations in the pore water and subsequent precipitation of uranium and non-uranium compounds. The increased ionic strength of the pore water due to mineral dissolution or solutes added with the waste, impact uranium transport by decreasing uranium sorption once pore water is buffered to near neutral $\mathrm{pH}$. The combination of these geochemical processes and the hydraulic driving forces related to waste disposal volume and disposal rate are important to consider when evaluating the fate and transport of uranium in the vadose zone. The following sections provide additional detail about these controlling processes.

\subsubsection{Acid Neutralization and Mineral Dissolution}

Acid neutralization results in rapid $(<10 \mathrm{~h})$ carbonate and phosphate dissolution and slower $(100 \mathrm{~s}$ of hours) clay dissolution (Szecsody et al. 2013). Aqueous ions increase mainly because of mineral dissolution but also from desorption. Key constituents whose concentrations are increased in the pore water include calcium and carbonate, phosphate, ferrous and ferric iron, aluminum, silica, potassium, and naturally occurring uranium. Calcium, carbonate, and phosphate concentrations increase rapidly (1-10 h). 
Other constituent concentrations peak later $(10-100 \mathrm{~h})$. All constituents decline in concentration after several hundreds of hours of contact time in these batch experiments. The maximum concentrations of ions in these experiments contacting sediments with $\mathrm{pH} 2$ solution were generally significantly greater than could be desorbed, supporting the interpretation of mineral dissolution during acid neutralization. Observed silica/aluminum molar ratios suggest 2:1 clay dissolution was occurring. Ferrous and ferric iron may be from dissolution of clays or iron oxides. The relative amounts of ferrous and ferric iron varied between different sediments. However, in all but one sediment sample, ferrous iron dominated. Increases in aqueous uranium concentrations were observed in acidic experiments where natural uranium may be released from dissolution of carbonates (i.e., uranium-carbonates) or iron oxides (which may contain mixed uranium-iron-oxide precipitates).

Experiments were also conducted with sediments with less intense acid amendment where the acid added was less than the proton adsorption capacity of the sediment and the $\mathrm{pH}$ increased significantly over time (i.e., related to conditions at greater depth as the solution is neutralized along a flow path) (Szecsody et al. 2013). The same processes occurred as described above for $\mathrm{pH} 2$ experiments, but to a lower extent.

The observed average proton adsorption capacities for the Hanford Site sediments ranged from 100 to $5750 \mu \mathrm{eq} / \mathrm{g}$, and are highest in the $\mathrm{CaCO}_{3}$-rich Cold Creek Unit (average $3310 \mu \mathrm{eq} / \mathrm{g}$ ), followed by the Hanford formation (average $483 \mu \mathrm{eq} / \mathrm{g}$ ), and lowest in the Ringold Formation (340 $\mu \mathrm{eq} / \mathrm{g}$ ) (Szecsody et al. 2013). In acidic conditions, minerals that have proton donation or adsorption capacity include $\mathrm{CaCO}_{3}$ $(20,000 \mu \mathrm{mol} / \mathrm{g})$, soil organic matter $(2000 \mu \mathrm{mol} / \mathrm{g})$, vermiculite (1500-2000), smectites (800-1500), allophane (200-500), illlite (200--400), chlorite (48-115; Villiers and Jackson 1967), kaolinite (10-50), and Fe, Al-oxides (50-400; Sumner et al. 2000). Therefore, in the Hanford Site, arid sediments with $<0.001 \%$ organic carbon, dissolution of $\mathrm{CaCO}_{3}$ is hypothesized to control acidic proton adsorption capacity for sediments with high carbonate concentrations, and clays are hypothesized to control the acidic proton adsorption capacity at low-carbonate concentrations. In the Hanford Central Plateau, wastes disposed at the surface would first contact the Hanford formation where the proton adsorption capacity is equivalent to about 0.9 mole of acidity per liter of soil volume assuming a porosity of 0.3 . Thus, a single pore volume of $3 \mathrm{~N}$ solution would consume the neutralization capacity in one pore volume (assuming saturated conditions). With multiple pore volumes disposed, even low acid concentrations could overwhelm this capacity near the waste disposal location.

Evaluating the hypothesis of the proton consumption being controlled by carbonates shows good agreement between measured proton consumption and predicted proton consumption only for sediments with $>2 \%$ carbonate (Szecsody et al. 2013). Sediments with $<2 \%$ carbonate still had significant proton uptake, which was related to the dissolution of other minerals. The total fraction of clay in the sediments did not correlate with proton uptake for these low-carbonate sediments. Prediction of proton adsorption capacity from clays would require identification of specific clays (i.e., vermiculite, smectites, allophane, and illite) that have been shown to contribute to proton adsorption capacity.

\subsubsection{Uranium and Non-Uranium Precipitates}

Uranium (U(VI)) aqueous speciation in the presence of aqueous ions measured from acid treatment of sediments was predicted using geochemical simulations (Szecsody et al. 2013). Predicted uranium speciation at $\mathrm{pH} 2$ to 2.5 shows high aqueous solubility of the uranyl cation. Uranium-carbonates and 
uranium-phosphates dominate uranium aqueous species in the acidic to neutral $\mathrm{pH}$, with a large decrease in uranium solubility (about two orders of magnitude) in the $\mathrm{pH} 3$ to 5 region as a result of uraniumphosphate (and possibly uranium-carbonate) precipitation. As the $\mathrm{pH}$ increases further to $\mathrm{pH} 7$, uranium solubility increases due to the predominance of uranium-carbonate species (i.e., $\mathrm{Ca}_{2} \mathrm{UO}_{2}\left(\mathrm{CO}_{3}\right)_{3}$ aq and $\left.\mathrm{CaUO}_{2}\left(\mathrm{CO}_{3}\right)_{3}{ }^{2-}\right)$. Because phosphate is present in significantly lower concentrations relative to carbonate (20x to $200 \mathrm{x}$ ), equilibrium predictions of primarily uranium-phosphate precipitation at $\mathrm{pH} 2.5$ to 5 depend on the presence of available phosphate. In the field, solubility reactions may result in initial uraniumphosphate precipitation (i.e., near the disposal location), then, when phosphate is depleted, uraniumcarbonate precipitation (i.e., somewhat deeper along the flow path). Finally, low fluoride concentrations measured in the pore water with acidic treatment result in low concentrations of uranium-fluoride aqueous complexes in the acidic region. However, if high fluoride concentrations were present in disposed waste, uranium-fluoride aqueous species $\left(\mathrm{UO}_{2} \mathrm{~F}_{3}^{-}, \mathrm{UO}_{2} \mathrm{~F}_{2}, \mathrm{UO}_{2} \mathrm{~F}_{4}^{-2}\right)$ could be significant when the $\mathrm{pH}$ is less than $\mathrm{pH}$ 7, and could limit uranium-carbonate and uranium-phosphate precipitation.

Uranium reduction is another potential contributor to uranium precipitation. The ferrous iron produced from dissolution reactions could reduce uranium, if adsorbed to iron oxide surfaces (Liger et al. 1999) resulting in U(IV) precipitates, although adsorption of ferrous iron would only occur once the acidic conditions were $\mathrm{pH}$ buffered to greater than $\mathrm{pH}$ 6. However, there were no significant differences in uranium sorption/precipitation response for batch experiments under acidic conditions that were conducted under atmospheric conditions compared to those in a controlled atmosphere with no measureable oxygen and carbon dioxide (Gartman et al. 2014). These data suggest that reductive processes induced by acid neutralization of the tested Hanford Site sediments are not a significant contributor to overall uranium partitioning to solids at low $\mathrm{pH}$.

Non-uranium mineral phases predicted to precipitate with a rise in $\mathrm{pH}$ that may coat uranium surface phases and influence uranium aqueous concentration include diaspore $(\mathrm{pH}>3)$, hematite (all $\mathrm{pH})$, dolomite (all $\mathrm{pH}$ ), quartz (pH 1 to 8), and hydroxyapatite ( $\mathrm{pH} 4$ to 8).

\subsubsection{Uranium Sorption and Transport}

Infiltration of uranium with $\mathrm{pH} 8$ groundwater (used for baseline comparison to co-contaminant cases) through a 3-m-long sediment column showed retarded uranium transport (retardation factor of 1.43) with a peak effluent concentration $40 \%$ higher than the influent, and an effluent uranium mass 2.0 times that of the influent (Szecsody et al. 2013). These effluent uranium data indicate that some desorption of natural uranium from the sediment occurred. For uranium infiltration in acidic waste, significant rapid (i.e., hours) carbonate and slow (i.e., 100s of hours) clay dissolution resulted, releasing significant sediment-associated uranium. The extent of uranium release and mobility change was a function of the acid content of the added waste in comparison to the sediment proton adsorption capacity. Infiltration of a weak acid (i.e., $0.01 \mathrm{M} \mathrm{HNO}_{3}$, less than sediment proton adsorption capacity) resulted in nearly the same effluent mass and peak concentration as the groundwater case, but 1.7 times more rapid uranium movement. The more rapid uranium movement was interpreted to be largely caused by the higher ionic strength solution suppressing uranium sorption. In contrast, infiltration of a strong acid (i.e., $4 \mathrm{M} \mathrm{HNO}_{3}$, exceeding the sediment proton adsorption capacity) resulted in three times more effluent uranium mass, a 5 times higher peak effluent uranium concentration, and 2.4 times more rapid uranium transport, relative to the groundwater infiltration case. Uranium extractions showed that these results were caused by considerable uranium leaching in sediments near the column influent, some uranium 
precipitation at greater depth (likely as uranium-phosphates and uranium-carbonates), and desorption of nearly all of the adsorbed natural uranium on the sediment. At field scale, below the zone of neutralization, further migration may be predictable from sorption changes due to ionic strength and uranium concentration (Tokunaga et al. 2004).

Sorption experiments demonstrated that uranium behavior in regions of the subsurface with low $\mathrm{pH}$ (e.g., $\mathrm{pH}$ 2) shows increasing sorption of uranium to the solid phase with large increases in ionic strength and sodium nitrate concentration (i.e., $1 \mathrm{M}$ sodium nitrate increased to $8 \mathrm{M}$ sodium nitrate) (Gartman et al. 2014). This behavior would be transient and occur during disposal, likely only in zones where the neutralization capacity became exhausted. Batch sorption experiments at $\mathrm{pH} 5$ showed nearly complete partitioning of uranium to the solid phase. Subsequent sediment analyses, consistent with geochemical simulation results and the data presented above, show that uranium precipitation is significant at $\mathrm{pH} 5$ under the conditions induced by acid neutralization. These sediment analyses show the presence of high uranium concentration zones on sediment surfaces, including uranyl phosphates (e.g., metaautunite $\left[\mathrm{Ca}\left(\mathrm{UO}_{2}\right)_{2}\left(\mathrm{PO}_{4}\right)_{2} \bullet 10-12\left(\mathrm{H}_{2} \mathrm{O}\right)\right]$ and phosphuranylite $\left.\left[\mathrm{KCa}\left(\mathrm{H}_{3} \mathrm{O}\right)_{3}\left(\mathrm{UO}_{2}\right)_{7}\left(\mathrm{PO}_{4}\right)_{4} \mathrm{O}_{4} \bullet 8\left(\mathrm{H}_{2} \mathrm{O}\right)\right]\right)$. Geochemical modeling suggests precipitation of uranium-phosphates and uranium-carbonates as acidic $\mathrm{pH}$ increases between $\mathrm{pH} 3$ and $\mathrm{pH} 5$.

\subsubsection{Hydraulic Considerations}

As discussed in the preceding sections, acid neutralization and therefore the related precipitation processes are kinetic processes. The residence (contact) time of the disposed solutions in the sediments is important. Thus the rate of waste solution infiltration is important in determining the zone of neutralization reactions and subsequent zone of precipitation. In addition, sediments have a finite acid neutralization capacity. Thus, the amount of acidity added is also important in evaluating the size of the geochemical reaction zones. These interpretations also need to consider the unsaturated threedimensional (3-D) flow characteristics of the vadose zone, in contrast to the saturated batch experiments or 1-D unsaturated flow conditions in the soil columns. However, estimates for the size of the geochemical reaction zones and therefore, the location of indications for these processes can be made using the geochemistry information, disposal characteristics, and subsurface hydraulic flow and transport information for a specific site. This report does not present this type of assessment because it is highly site-specific. Rather, the report provides the context of the geochemical component of the system and sequence of processes that need to be considered in the site-specific analysis.

\subsection{Recommended Characterization Approach for Acidic Waste Sites}

Based on the above experiments, key signatures at acidic sites would include depleted carbonate and uranium beneath the disposal site (especially for strong acid sites), remnant uranium precipitates at the downgradient margin of the acid neutralization zone, and higher ionic strength pore water deeper in the vadose zone with some suppression of uranium sorption processes for neutralized pore water.

Two elements of uranium fate and transport can be evaluated with targeted uranium characterization of borehole sediment samples using the information from the conceptual model framework presented in this report. The first element is to provide input to estimating the mobile uranium mass that has the potential to impact groundwater. The second element is to provide input to selection of appropriate transport parameters for estimating the flux of mobile uranium to the groundwater. This section discusses 
the type of characterization that can be used as a technical basis to guide components of evaluating a specific uranium waste site in terms of potential impact on groundwater and the related remediation decisions for the vadose zone uranium contamination.

\subsubsection{Estimating Mobile Uranium Mass}

Initial estimates of uranium mass disposed to a waste site are available from the historical waste discharge inventory records or estimates. Waste discharge information should also be reviewed for description of the waste acidity, discharge volume, and the timing and duration of the discharge. Basic calculations from these data are the discharged uranium mass and associated bulk uranium concentration. In addition, estimate of baseline waste transport (e.g., as conducted by Eslinger et al. 2006) using the discharged inventory can be used as an initial interpretation of uranium flux to groundwater. These estimates can then be refined using the geochemical process interpretations discussed herein.

An important calculation is the minimum volume of sediment required to neutralize the added acidity based on the waste discharge information and a specific neutralization capacity of 0.9 moles of acidity per liter of soil volume (for Hanford formation sediment, assuming a porosity of 0.3 ). Thus, a discharge of $10,000 \mathrm{~L}$ with $0.1 \mathrm{~N}$ acid would be 1000 moles of acidity requiring about 1100 liters of soil to neutralize. Because of the rapid rate of acid neutralization, this "minimum" estimate is reasonable to apply for acidic waste disposal sites. However, the distribution of the neutralization zone may not be uniform; hydraulic considerations must be used to interpret the shape of the neutralization zone and guide selection of appropriate characterization borehole locations. Waste discharge volume, timing, and duration in conjunction with subsurface hydraulic properties need to be considered in this interpretation. Sites with larger neutralization zones would be more likely to 1) have some contribution of natural uranium added to the pore water by dissolution during neutralization and 2) have phosphate dissolution that would lead to uranium precipitates such that a portion of the added (or natural uranium) will be functionally immobile. Borehole characterization, as discussed below, can provide data to evaluate these factors.

Borehole locations should consider obtaining a vertical profile of data as close as possible to the waste flow path in the vadose zone. While the flow path is difficult to precisely pick, generally vertical flow directly beneath the waste site would be a reasonable assumption. From borehole samples, a vertical profile of sediment $\mathrm{pH}$ and carbonate content (especially shallow underneath the disposal facility) should be obtained as a way to evaluate the acid neutralization zone. Sites with strong acid disposal that overwhelmed the neutralization capacity in shallow sediments may show a signature of low $\mathrm{pH}$ and lowcarbonate content transitioning to higher carbonate content and $\mathrm{pH}$ outside the neutralization zone. The borehole data would provide an estimate for the depth and therefore volume of this zone. Such information would be compared to waste discharge estimates and interpreted with respect to the extent and intensity of acid neutralization reactions for the specific site.

In conjunction with the above borehole information, a vertical profile of uranium concentration using a sequential extraction technique (Section 1.2) is recommended. These data are important for 1) assessing leaching of natural uranium from the acid neutralization zone, 2) identifying zones of uranium precipitation (immobilization), 3) assessing the fraction of mobile and functionally immobile uranium as a function of depth, and 4) evaluating the vertical distribution of mobile uranium concentration in pore water. 


\subsubsection{Estimating Transport Parameters}

In addition to the characterization information listed in Section 3.3.1, borehole samples should be analyzed to determine the vertical profile of pore-water ionic strength. As demonstrated by Szecsody et al. (2013) and Gartman et al. (2014), the transport characteristics of uranium change with increased porewater ionic strength. For sites where the impact of disposed waste on pore-water ionic strength has or will propagate for a large portion of the vadose zone, information from Szecsody et al. (2013) and Gartman et al. (2014), or site-specific studies should be used in conjunction with existing uranium transport information (e.g., Zachara et al 2007) to evaluate the appropriate transport parameters for uranium. This information would need to be combined with hydraulic infiltration information for the site, which could be augmented through collection of hydrologic data from borehole samples. 


\subsection{Alkaline Waste-Site Conceptual Model}

A general conceptual model for uranium at waste sites where alkaline wastes were disposed is described in this section for use as a template in developing a site-specific conceptual model. Primary experimental support for the conceptual model is described by Szecsody et al. (2013). The conceptual model incorporates the impacts of alkaline neutralization on uranium transport as influenced primarily by non-uranium-bearing mineral dissolution/precipitation and changes in uranium aqueous species partitioning (i.e., sorption) that are imposed by this mineral dissolution/precipitation and the waste fluid constituents. Impacts of other waste constituents (e.g., complexants) would need to be considered in addition to the processes discussed in this section.

\subsection{Conceptual Model for Alkaline Waste Sites}

Uranium fate and transport in the vadose zone beneath alkaline waste sites are impacted by the following processes. Mineral dissolution occurs during neutralization of alkaline solutions and results in moderate increases in the carbonate concentration in pore water, followed by a slower increase in silica concentration, likely from montmorillonite, muscovite, and kaolinite dissolution. The extent to which mineral dissolution occurs at uranium disposal sites depends on the concentration and mass of the alkaline solution relative to the sediment $\mathrm{OH}^{-}$adsorption capacity. The rate of alkaline solution neutralization is slower than observed for acid neutralization (Section 3.0). Under alkaline conditions that induce mineral dissolution, aqueous uranium concentration decreases rapidly through precipitation of hydrous uranium silicates, in particular as Na-boltwoodite, while $\mathrm{pH}$ remains above $\mathrm{pH}$ 9.5. Released then adsorbed ferrous iron may reduce some of the uranium, but this may be a temporary condition. However, reduced and adsorbed uranium on sediment surfaces may be coated by silicate precipitation and become functionally immobile. Uranium sorption can be decreased by increases in pore-water ionic strength caused by sediment dissolution or from the ionic strength of the disposed-waste solution (e.g., from sodium nitrate). Figure 2 depicts the conceptual model for dominant geochemical processes impacting uranium fate and transport beneath alkaline waste sites. This conceptual model must also incorporate consideration of water and waste volume discharged and hydraulic transport conditions (not shown). Additional discussion of controlling geochemical processes and relevant mineralogy are described in the following sections. A recommended characterization approach for alkaline waste sites is then provided. 


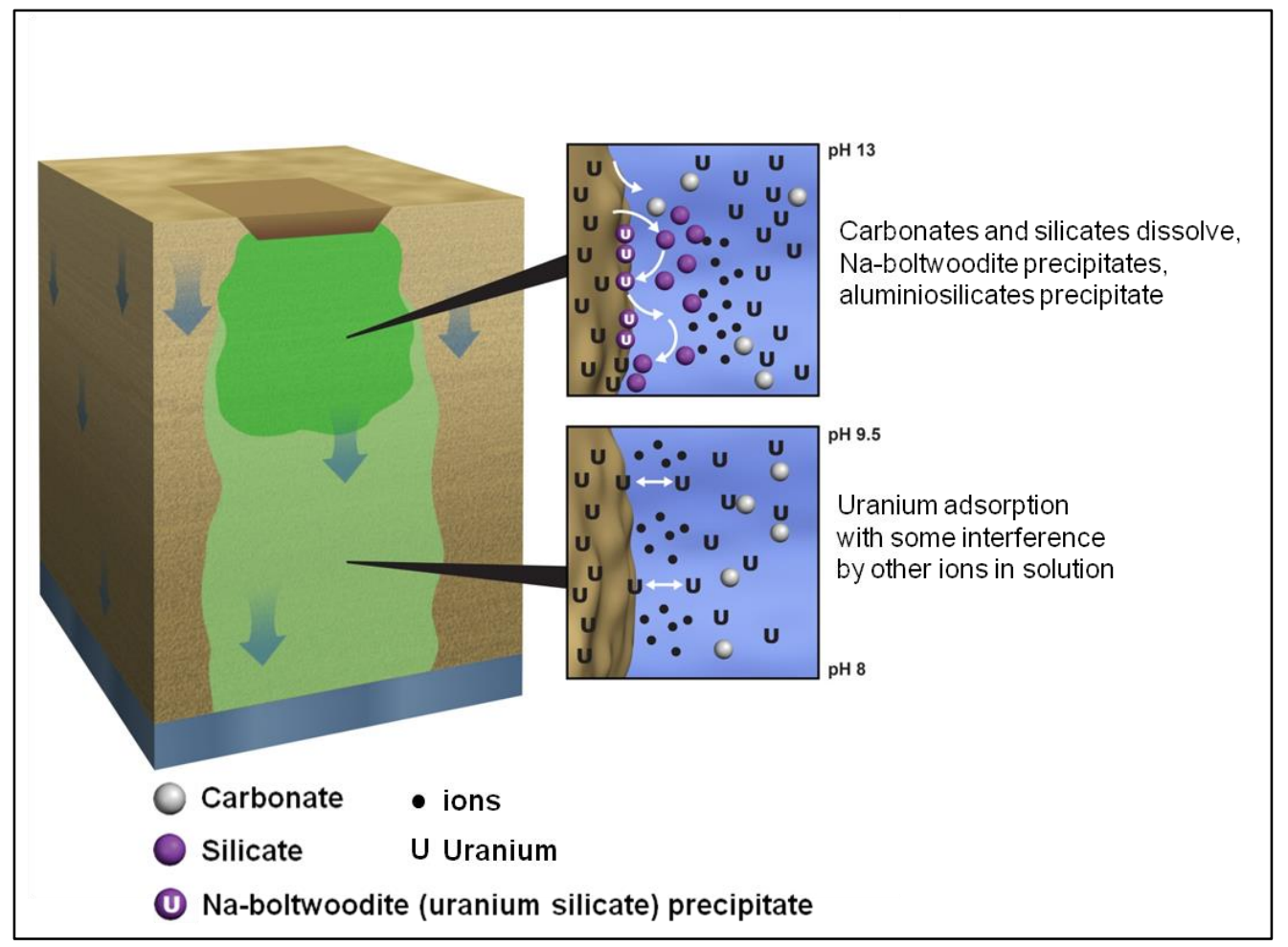

Figure 2. Geochemical conceptual model showing dominant processes for alkaline waste sites as summarized in Section 4.1 and described with additional details in Section 4.2.

\subsection{Controlling Processes for Alkaline Waste Sites}

Contact of alkaline waste with sediments induces alkaline neutralization reactions. The neutralization rate and capacity for sediments in the Hanford Central Plateau is lower than the acid neutralization rate and capacity of these sediments (Section 3.0). Therefore, dissolution reactions and resulting precipitation would occur to a greater depth with alkaline waste disposal compared to acidic waste disposal under the same hydraulic conditions. Alkaline neutralization is dominated by aluminosilicate dissolution along with some carbonate dissolution. Mineral dissolution leads to increased ion concentrations in the pore water and, while the $\mathrm{pH}$ remains about $\mathrm{pH}$ 9.5, uranium precipitation as a silicate (predominantly sodium boltwoodite) occurs. Precipitation of non-uranium compounds also occurs as the $\mathrm{pH}$ is neutralized. The increased ionic strength of the pore water due to mineral dissolution or solutes added with the waste impact uranium transport by decreasing uranium sorption. The combination of these geochemical processes and the hydraulic driving forces related to alkaline waste volume and disposal rate are important to consider when evaluating the fate and transport of uranium in the vadose zone. The following sections provide additional detail about these controlling processes.

\subsubsection{Alkaline Neutralization and Mineral Dissolution}

Alkaline neutralization results in a rapid $(<10 \mathrm{~h})$, but moderate, increase in carbonate concentration, followed by a slow (10s to 100s of hours) increase in silica concentration, likely from montmorillonite, muscovite, and kaolinite dissolution (Szecsody et al. 2013). Aqueous ion concentrations increase mainly because of mineral dissolution but also because of desorption. Key constituents whose concentrations are 
increased in the pore water include carbonate, ferrous iron, aluminum, silica, and potassium. Carbonate and ferrous iron concentrations increase moderately, but rapidly $(1-10 \mathrm{~h})$, with other constituents peaking later $(10-100 \mathrm{~h})$. Alkaline treatment of sediments also resulted in the release of small concentrations of potassium, ferrous iron, chloride, fluoride, and sulfate, but no measureable calcium or magnesium, likely due to rapid precipitation of hydroxides. The maximum concentrations of these ions in experiments contacting sediments with $\mathrm{pH} 13$ solution were generally significantly greater than could be desorbed from the sediment, supporting the interpretation of mineral dissolution during alkaline neutralization. Because sodium hydroxide was used to create alkaline conditions in the Szecsody et al. (2013) study, sodium concentration could not be interpreted with respect to dissolution and desorption. However, in a previous study of alkaline treatment of sediment with ammonium hydroxide, increased pore water concentrations of sodium are reported (Szecsody et al. 2012). Although the same concentration of silica was dissolving from sediment minerals over the same 10- to 100-h time scale as occurred during acidic treatment (Section 3.0), about an order of magnitude less aluminum dissolved. Silica-containing minerals such as quartz, montmorillonite, muscovite, and kaolinite were likely dissolving under alkaline conditions (Wan et al. 2004b; Szecsody et al. 2012), which should also produce substantial alumina.

Aluminosilicate precipitation may account for lower aqueous aluminum values, and include cancrinite, zeolite (Wan et al. 2004b; Qafoku et al. 2003), sodalite, and zeophyllite precipitate (Barnes et al. 1999; Buck and McNamera 2004; Buhl and Lons 1006).

In contrast to proton adsorption capacities, the observed average $\mathrm{OH}$ - adsorption capacities were similar for the Hanford, Cold Creek, and Ringold sediments (338, 369, and $437 \mu \mathrm{meq} / \mathrm{g}$, respectively) (Szecsody et al. 2013). Although the $\mathrm{OH}^{-}$adsorption capacity of these sediments was smaller than proton adsorption capacities, it is equivalent to about 0.6 mole of alkalinity per liter of soil volume assuming a porosity of 0.3 . Thus, a single pore volume containing $2 \mathrm{M}$ of hydroxide solution would consume the neutralization capacity (assuming saturated conditions). With multiple pore volumes disposed, even low $\mathrm{OH}^{-}$concentrations could overwhelm this capacity. Although there was some rapid $\mathrm{OH}^{-}$adsorption capacity (i.e., $<1 \mathrm{~h}$ ), most of the $\mathrm{OH}^{-}$adsorption capacity occurred over 10 s to 100 s of hours, reflecting the predominance of slower dissolving aluminosilicates. Because these rates are slower than for acid neutralization, an alkaline solution would, under the same hydraulic driving forces, be expected to infiltrate to a greater depth than an acidic solution before being neutralized. Others have also observed that the $\mathrm{OH}^{-}$adsorption capacity of a Hanford sediment controlled the magnitude of alkaline injection solutions (varying from $\mathrm{pH} 9$ to 13) that could be fully neutralized under the experimental conditions (Wan et al. 2004a).

Experiments were also conducted with sediments with less intense alkaline amendment where the alkalinity added was less than the $\mathrm{OH}^{-}$adsorption capacity of the sediment and the $\mathrm{pH}$ decreased over time from $\mathrm{pH} 13$ to $\mathrm{pH} 12$ (i.e., related to conditions at greater depth as the solution is neutralized along a flow path) (Szecsody et al. 2013). Compared to aqueous silica concentrations for tests with the strongly alkaline amendment ( $\mathrm{pH}$ maintained at $\mathrm{pH}$ 13), tests with less intense alkaline amendment showed a more significant decrease in silica concentration, indicative of silica precipitation. Little difference in aqueous aluminum was observed. Although aqueous uranium should precipitate as hydrous uranium silicates (e.g., Na-boltwoodite), the uranium concentrations are orders of magnitude lower than aqueous silica concentrations, so they do not cause a measurable influence on overall observed aluminosilicate precipitation for either type of alkalinity treatment. 


\subsubsection{Uranium and Non-Uranium Precipitates}

In contrast to acid systems, under highly alkaline ( $\mathrm{pH} 13$ ) conditions, uranium-silicate precipitation (Na-boltwoodite) is a dominant process with respect to the fate of uranium. The uranium speciation predicted in geochemical modeling shows Na-boltwoodite should precipitate over a $\mathrm{pH}$ range of $\mathrm{pH} 13$ to pH 9.5 (Szecsody et al. 2013). As the $\mathrm{pH}$ decreases below $\mathrm{pH} 9.5$, uranium solubility increases, dominated by $\mathrm{Ca}_{2} \mathrm{UO}_{2}\left(\mathrm{CO}_{3}\right)_{3}$ aq, $\mathrm{CaUO}_{2}\left(\mathrm{CO}_{3}\right)_{3}{ }^{-2}$, and uranium-silicate precipitation becomes insignificant. Non-uranium minerals that have previously been shown to precipitate with alkaline treatment of sediment include cancrinite (Bickmore et al. 2001; Zhao et al. 2004), sodium silicate, talc (Wan et al. 2004a), sodalite, hydrobiotite, brucite, and goethite (Qafoku et al. 2004, 2008). Geochemical simulations conducted with and without the sodium nitrate (a commonly co-disposed compound in alkaline wastes) show little influence on uranium speciation in the alkaline region.

For both strong and less intense alkaline treatments, measured aqueous uranium concentration after $1 \mathrm{~h}$ of contact time was low $(0.006$ to $0.3 \mu \mathrm{mol} / \mathrm{L})$ relative to the initial uranium concentration of $0.84 \mu \mathrm{mol} / \mathrm{L}$ (Szecsody et al. 2013). Thus, substantial sorption or uranium-silicate precipitation occurred rapidly under these conditions. Over $1200 \mathrm{~h}$, dissolved uranium concentrations decreased one to two orders of magnitude in Hanford and Cold Creek sediment experiments, but decreased only slightly in Ringold sediment experiments. It is likely that the initial low aqueous uranium concentration after $1 \mathrm{~h}$ of contact time reflects sorption and uranium-silicate precipitation, and the slow continued decrease in aqueous uranium over 10 s to 100 s of hours reflects continued uranium-silicate precipitation. The negligible difference in uranium behavior between experiments with strong and less intense alkalinity treatments may be because Na-boltwoodite solubility (and related precipitation of uranium) is constant over a wide alkaline $\mathrm{pH}$ range. In a previous study, resident pore water in sediment microfractures high in dissolved silica was hypothesized to react with silica-poor uranium-laden water diffusing into these sediment microfractures, resulting in Na-boltwoodite precipitation (McKinley et al. 2006).

Released ferrous iron from mineral dissolution, if adsorbed to iron oxide surfaces (Liger et al. 1999), may reduce some of the uranium (as has been observed for chromium, Zachara et al 2004), though presence of reduced uranium may be a temporary condition. However, reduced and adsorbed uranium on sediment surfaces may be coated by aluminosilicate precipitation that is observed in alkaline systems and the uranium may become functionally immobile and stabilized with respect to reoxidation.

\subsubsection{Uranium Sorption and Transport}

Infiltration of uranium with $\mathrm{pH} 8$ groundwater (used for baseline comparison to co-contaminant cases) through a 3-m-long sediment column showed retarded uranium transport (retardation factor of 1.43) with a peak effluent concentration $40 \%$ higher than the influent, and effluent uranium mass 2.0 times that of the influent (Szecsody et al. 2013). These effluent uranium data indicate that some desorption of natural uranium from the sediment occurred. For uranium infiltration in alkaline waste, significant slow aluminosilicate dissolution occurred and resulted in precipitation of uranium-silicate (Naboltwoodite) and desorption of some natural uranium on the sediment due to the high ionic strength of the infiltration solution. Once the $\mathrm{pH}$ was buffered to below about $\mathrm{pH} 9.5$ in the columns, Na-boltwoodite precipitation would cease. Uranium migration from infiltration of the strong alkaline solution $(0.1 \mathrm{M}$ $\mathrm{NaOH}, 1.0 \mathrm{M} \mathrm{NaNO}_{3}$ ) resulted in $60 \%$ greater effluent uranium mass and $60 \%$ higher peak uranium concentration than the groundwater infiltration case. However, the relative uranium transport velocity 
that was 1.7 times slower than it was for the groundwater case. At field scale, below the zone of neutralization, further migration may be predictable from sorption changes due to ionic strength and uranium concentration (Tokunaga et al. 2004).

\subsubsection{Hydraulic Considerations}

Hydraulic considerations for alkaline waste disposal sites are similar to those for acidic sites. However, because the alkaline neutralization capacity of Hanford sediments is lower and the alkaline neutralization rate is slower, deeper penetration of alkaline conditions may occur for the same hydraulic site conditions. Also, because Na-boltwoodite precipitates over a range of alkaline $\mathrm{pH}$ conditions and the $\mathrm{pH}$ may remain high throughout a large zone in the subsurface because of the slow neutralization rate, Na-boltwoodite may be a dominant precipitation product beneath alkaline waste sites.

As discussed in the preceding sections and similar to the discussion for acidic sites, alkaline neutralization and therefore the related precipitation processes are kinetic processes. The residence (contact) time of the disposed solutions and sediments is important. Thus the rate of waste solution infiltration is important in determining the zone of neutralization reactions and subsequent zone of precipitation. In addition, sediments have a finite alkaline neutralization capacity. Thus, the amount of alkalinity added is also important in evaluating the size of the geochemical reaction zones. These interpretations also need to consider the unsaturated 3-D flow characteristics of the vadose zone, in contrast to the saturated batch experiments or 1-D unsaturated flow conditions in the soil columns. However, estimates for the size of the geochemical reaction zones, and therefore the location of indications for these processes, can be made using the geochemistry information, disposal characteristics, and subsurface hydraulic flow and transport information for a specific site. This report does not present this type of assessment because it is highly site-specific. Rather, the report provides the context of the geochemical component of the system and sequence of processes that need to be considered in the sitespecific analysis.

\subsection{Recommended Characterization Approach for Alkaline Waste Sites}

Based on the above experiments, key signatures at alkaline waste disposal sites would include remnant uranium-silicate concentrations beneath the disposal site, perhaps over a large depth profile, and higher ionic strength pore water deeper in the vadose zone with some suppression of uranium sorption processes.

Two elements of uranium fate and transport can be evaluated with targeted uranium characterization of borehole sediment samples using the information from the conceptual model framework presented in this report. The first element is to provide input to estimating the mobile uranium mass that has the potential to impact groundwater. The second element is to provide input to selection of appropriate transport parameters for estimating the flux of mobile uranium to the groundwater. This section discusses the type of characterization that can be used as a technical basis to guide components of evaluating a specific uranium waste site in terms of potential impact on groundwater and the related remediation decisions for the vadose zone uranium contamination. 


\subsubsection{Estimating Mobile Uranium Mass}

Initial estimates of uranium mass for a waste site are available from historical waste discharge inventory records or estimates. Waste discharge information should also be reviewed for description of the waste alkalinity, discharge volume, and the timing and duration of the discharge. Basic calculations from these data are the discharged uranium mass and associated bulk uranium concentration. In addition, estimates of baseline waste transport (e.g., as conducted by Eslinger et al. 2006) using the discharged inventory can be used as an initial interpretation of uranium flux to groundwater. These estimates can then be refined using the geochemical process interpretations discussed herein.

An important calculation is the minimum volume of sediment required to neutralize the added alkalinity based on the waste discharge information and a specific neutralization capacity of 0.6 moles of alkalinity per liter of soil volume (for Hanford formation sediment, assuming a porosity of 0.3 ). Thus, a discharge of 10,000 L with $0.1 \mathrm{M}$ base $\left(\mathrm{OH}^{-}\right)$would be 1000 moles of alkalinity requiring about $1600 \mathrm{~L}$ of soil to neutralize. Because of the slower rate of alkaline neutralization, this "minimum" estimate may need to be expanded to a larger volume of sediment if the waste discharge rate was rapid. As for acidic sites, the distribution of the neutralization zone may not be uniform; hydraulic considerations must be used to interpret the shape of the neutralization zone and guide selection of appropriate characterization borehole locations. Waste discharge volume, timing, and duration in conjunction with subsurface hydraulic properties need to be considered this interpretation. Sites with larger neutralization zones would be more likely to have more of the discharged uranium precipitated as Na-boltwoodite or coated with aluminosilicate precipitates. Thus, these sites may have a larger fraction of disposed uranium converted to functionally immobile phases with a decrease in the total mass of uranium that will reach the groundwater at a flux that could create a groundwater contamination plume. Borehole characterization, as discussed below, can provide data to evaluate this factor.

Borehole locations should consider obtaining a vertical profile of data as close as possible to the waste flow path in the vadose zone. While the flow path is difficult to precisely pick, generally vertical flow directly beneath the waste site would be a reasonable assumption. From borehole samples, a vertical profile of uranium concentration using a sequential extraction technique (Section 1.2) is recommended. These data are important to 1) identify zones of significant Na-boltwoodite or uranium coated by aluminosilicate precipitates 2) assess the fraction of mobile and functionally immobile uranium as a function of depth, and 3) evaluate the vertical distribution of mobile uranium concentration in pore water. Uranium contamination in shallow sediments at Hanford Central Plateau waste sites has included uranium-silicate [Na-boltwoodite; $\mathrm{Na}\left(\mathrm{UO}_{2}\right)\left(\mathrm{SiO}_{4}\right) * 1.5 \mathrm{H}_{2} \mathrm{O}$; Liu et al. 2004)], uranophane $\left[\mathrm{Ca}\left(\mathrm{UO}_{2}\right)_{2}\left(\mathrm{SiO}_{3} \mathrm{OH}\right)_{2}\left(\mathrm{H}_{2} \mathrm{O}\right)_{5}\right]$, and uranium-calcite coprecipitates (Um et al. 2009). Figure 3 illustrates sequential extraction data of samples from a borehole beneath the U Tank Farm in the Hanford Central Plateau. Shallow samples show significantly higher uranium concentrations and a large fraction of uranium within low-mobility fractions. In particular, the $\mathrm{pH} 2.3$ acetate fraction (yellow color, Section 1.2) has been shown to include Na-boltwoodite (Szecsody et al. 2012). 




Figure 3. Sequential extraction of sediment samples beneath the U Tank Farm in the Hanford Central Plateau using the technique described in Section 1.2 (after Szecsody et al. 2010b). Bar length corresponds to the percentage of total uranium within each extraction. Total uranium concentrations for each sample are displayed. The number on the right side of the figure is the depth of the sample in feet below ground surface.

\subsubsection{Estimating Transport Parameters}

In addition to the characterization information listed in Section 4.3.1, borehole samples should be analyzed to determine the vertical profile of pore-water ionic strength. As demonstrated by Szecsody et al. (2013) and Gartman et al. (2014), the transport characteristics of uranium change with increased porewater ionic strength. For sites with where the impact of disposed waste on pore-water ionic strength has or will propagate for a large portion of the vadose zone, information from Szecsody et al. (2013) and Gartman et al. (2014), or site-specific studies should be used in conjunction with existing uranium transport information (e.g., Zachara et al 2007) to evaluate the appropriate transport parameters for uranium. This information would need to be combined with hydraulic infiltration information for the site, which could be augmented through collection of hydrologic data from borehole samples. 


\subsection{Conclusions and Implications for Uranium Transport in the Hanford Vadose Zone}

The chemistry of the disposed-waste solution impacts uranium transport through the vadose zone and the rate at which it discharges to the groundwater. Thus, evaluation of subsurface uranium distribution from waste sites, including consideration of the type and capacity of relevant geochemical processes induced through disposed-waste chemistry, is important to quantifying the extent to which natural attenuation processes will mitigate risk to groundwater and help define targets for any additional remedial actions, if needed. This study examined the impact of acidic and alkaline waste disposal on uranium transport in the vadose zone. Information from waste-chemistry evaluation can also be important for selecting borehole sample locations, identifying analyses diagnostic of uranium fate and transport, and interpreting characterization data in terms of future contaminant flux to groundwater. In summary, information about the impact of geochemical reactions on uranium fate and transport near the disposal facility, when combined with the extensive information describing uranium fate and transport at near background $\mathrm{pH}$ conditions (e.g., Zachara et al. 2007), enables focused characterization to support effective fate and transport estimates for uranium in the subsurface. Figure 4 shows a composite of the key geochemical conceptual model elements for acidic and alkaline waste sites (see also Section 3.0, Figure 1 and Section 4.0, Figure 2 for additional details).

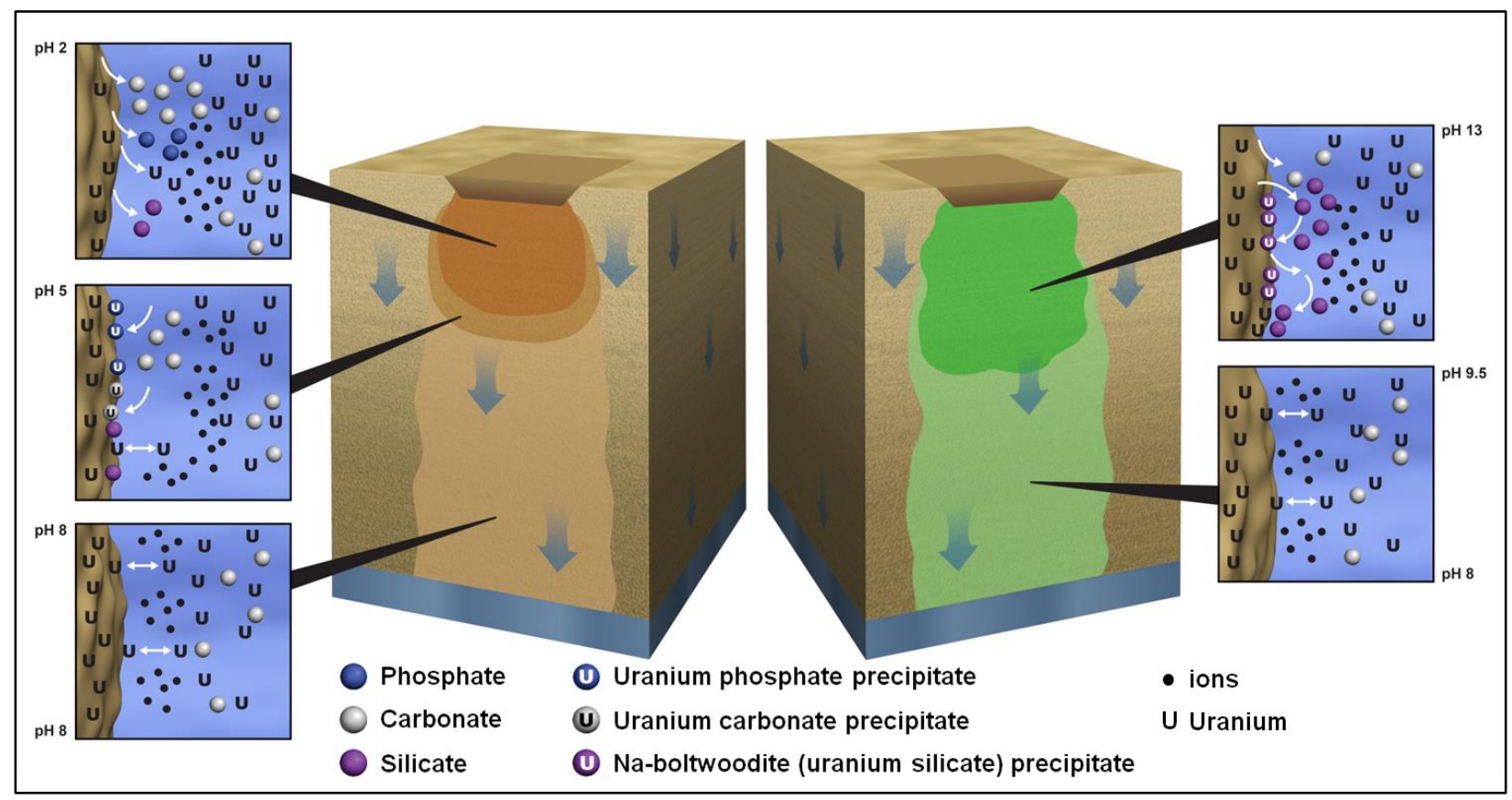

Figure 4. Composite geochemical model showing dominant processes for uranium at acidic and alkaline waste sites.

The geochemistry information provided by this study can be applied with respect to assessing individual waste sites in terms of quantifying natural attenuation and estimating the future discharge of uranium form the vadose zone to the groundwater. These estimates are needed to evaluate the baseline risk for a waste site and select an appropriate remediation approach, when needed. A previous estimate of potential impact on groundwater was conducted by Eslinger et al. (2006). However, incorporating the 
geochemical controls on uranium transport that are imposed based on the disposed-waste chemistry will help refine these previous estimates and can be incorporated into appropriate site assessment processes (e.g., Truex and Carroll 2013).

Applications of the geochemical information from this study are summarized below.

- Historically, uranium was disposed in waste solutions of varying waste chemistry at the Hanford Site Central Plateau. How uranium was distributed in the vadose zone during disposal, how it has continued to migrate through the vadose zone, and the magnitude of its potential impacts on groundwater are strongly influenced by geochemical reactions in the vadose zone. These geochemical reactions can be significantly influenced by the disposed-waste chemistry in the vadose zone near the disposal location. The information derived from the recommended characterization and conceptual model interpretation provided in this report, when combined with the extensive information describing uranium fate and transport at near background $\mathrm{pH}$ conditions, enables focused characterization to support effective fate and transport estimates for uranium in the subsurface.

- Acidic Site Conceptual Model Template (see also Section 3.0, Figure 1). Mineral dissolution caused by acidic solutions can increase aqueous carbonate and phosphate concentrations in the pore water and result in a slower increase in silica and aluminum concentrations, likely released during clay dissolution. Most cation concentrations in the pore water also increase significantly, predominantly from dissolution, but also from ion exchange. Infiltration of a strong acid can release sedimentassociated (e.g., native) uranium by causing sediment dissolution. As acidic solutions are neutralized by interaction with the sediment, uranium precipitation as phosphates and carbonates can occur. Other aqueous ion concentrations also decrease at this time, likely from quartz, diaspore, and dolomite precipitation. The acid buffering capacity and rate for Hanford sediments is mostly controlled by rapid carbonate dissolution and slow clay dissolution. In addition to dissolution and precipitation reactions, addition of acidic waste solutions can decrease uranium sorption due to increases in pore-water ionic strength that are caused by sediment dissolution or the ionic strength of the disposed-waste solution.

- Alkaline Site Conceptual Model Template (see also Section 4.0, Figure 2). Mineral dissolution can also be caused by alkaline solutions and result in moderate increases of the carbonate concentration in pore water, followed by a slower increase in silica concentration, likely from montmorillonite, muscovite, and kaolinite dissolution. Under these conditions, aqueous uranium concentration decreases rapidly through precipitation as Na-boltwoodite while $\mathrm{pH}$ remains above 9.5. Uranium sorption can be decreased by increases in pore-water ionic strength caused by sediment dissolution or the ionic strength of the disposed-waste solution (e.g., from sodium nitrate).

- The spatial distribution of characterization data describing the mobile and immobile uranium present in borehole sediment samples (e.g., sediment analysis based on variable extraction procedures) can be evaluated with respect to the dissolution and precipitation processes anticipated from the waste chemistry and disposal volumes. The geochemical data can, at minimum, be applied to provide a technically defensible explanation for the presence of immobile uranium and support the associated modifications of uranium transport assessments and adjustments to the expected uranium mass discharge to groundwater. Key precipitates are uranium-carbonates and uranium-phosphates (especially for $\mathrm{pH}$ conditions near $\mathrm{pH}$ 5) for acidic waste sites and $\mathrm{Na}$-boltwoodite for alkaline waste sites. 
- Waste-site information for the waste volume and waste acidity/alkalinity can be incorporated into the site conceptual model using sediment neutralization capacity and rate data to estimate the volumetric extent of the neutralization zone beneath the waste site and magnitude of the neutralization impact on geochemical conditions. This evaluation provides a basis for interpreting characterization data from the site and refining the conceptual model for input to uranium transport assessments.

- Waste-site pore-water chemistry data (e.g., ionic strength and dissolved constituent concentrations) can be interpreted to provide input to select appropriate geochemical and transport parameters for reactive transport calculations. Comparison of ionic strength and concentration of constituents, such as sodium, to background pore-water chemistry can be used to evaluate appropriate values for uranium sorption and, based on the spatial distribution of the pore-water chemistry, be used to refine the site conceptual model in terms of how transport would be expected to evolve over time as disposed wastes and pre-existing vadose zone pore-water mix. 


\subsection{Quality Assurance}

The PNNL Quality Assurance (QA) Program is based upon the requirements defined in DOE Order 414.1D, Quality Assurance and 10 CFR 830, Energy/Nuclear Safety Management, Subpart A - Quality Assurance Requirements (a.k.a. the Quality Rule). PNNL has chosen to implement the following consensus standards in a graded approach:

- ASME NQA-1-2000, Quality Assurance Requirements for Nuclear Facility Applications, Part 1, Requirements for Quality Assurance Programs for Nuclear Facilities.

- ASME NQA-1-2000, Part II, Subpart 2.7, Quality Assurance Requirements for Computer Software for Nuclear Facility Applications, including problem reporting and corrective action.

- ASME NQA-1-2000, Part IV, Subpart 4.2, Guidance on Graded Application of Quality Assurance (QA) for Nuclear-Related Research and Development.

The procedures necessary to implement the requirements are documented through PNNL's "How Do I...? (HDI) system, a system for managing the delivery of laboratory-level policies, requirements and procedures.

The DVZ-AFRI Quality Assurance Plan (Meier 2014) is the minimum applicable QA document for all Deep Vadose Zone-Applied Field Research Initiative (DVZ-AFRI) projects. This QA Plan also conforms to the QA requirements of DOE Order 414.1D, Quality Assurance, and 10 CFR 830, Subpart A, Quality Assurance Requirements. The DVZ-AFRI is subject to the Price-Anderson Amendments Act. The implementation of the DVZ-AFRI quality assurance program is graded in accordance with NQA-12000, Part IV, Subpart 4.2, Guidance on Graded Application of Quality Assurance (QA) for NuclearRelated Research and Development.

The work for this report was performed under the technology level of Applied Research. Applied Research consists of research tasks that acquire data and documentation necessary to ensure satisfactory reproducibility of results. The emphasis during this stage of a research task is on achieving adequate documentation and controls necessary to be able to reproduce results. 


\subsection{References}

10 CFR 830. 2001. Code of Federal Regulations. Title 10, Energy. Part 830, "Nuclear Safety Management.” Subpart A, "Quality Assurance Requirements.” Washington, D.C.

ASME (American Society of Mechanical Engineers). 2001. Quality Assurance Requirements for Nuclear Facility Applications. NQA-1-2000, New York.

Barnes MC, J Addai-Mensah, RR Gerson. 1999. The solubility of sodalite and cancrinite in synthetic spent Bayer liquor. Colloids and Surfaces A 157:101-116.

Bickmore BR, KL Nagy, JS Young, and JW Drexier. 2001. Nitrate-cancrinite precipitation on quartz sand in simulated Hanford tank solutions. Environmental Science and Technology 35(22):4481-4486.

Buck EC and BK McNamara. 2004. "Precipitation of nitrate-cancrinite in Hanford tank sludge." Environmental Science and Technology 38:4432-4438.

Buhl J-C and J Lons. 1996. "Synthesis and crystal structure of nitrate enclathrated sodalite Na8[A1SiO4]6 (NO3)2." Journal of Alloys and Compounds 235:41-47.

Catalano J, J McKinley, J Zachara, S Heald, S Smith, and G Brown. 2008. "Changes in Uranium Speciation Through a Depth Sequence of Contaminated Hanford Sediments." Environmental Science and Technology 40(8):2517-2524.

Corbin R, B Simpson, M Anderson, W Danielson, J Field, T Jones, and C Kincaid. 2005. Hanford Soil Inventory Model, Rev. 1. RPP-26744, CH2M Hill Hanford Group, Inc., Richland, Washington.

DOE (U.S. Department of Energy). 2011, as amended. Quality Assurance. DOE Order 414.1D, Washington, D.C.

Eslinger PW, CT Kincaid, WE Nichols, and SK Wurstner. 2006. A Demonstration of the System Assessment Capability (SAC) Rev. 1 Software for the Hanford Remediation Assessment Project. PNNL-16209, Pacific Northwest National Laboratory, Richland, Washington.

Gartman, BN, NP Qafoku, JE Szecsody, R. Kukkadapu, Z Wang, DM Wellman, and MJ Truex. 2014. Uranium fate in Hanford sediment altered by simulated acid waste solutions. Submitted Applied Geochemistry.

Ilton E, C Liu, W Yantasee, Z Wang, D Moore, A Felmy, and JM Zachara. 2006. "The dissolution of synthetic Na-boltwoodite in sodium carbonate solutions." Geochimica et Cosmochimica Acta $70: 4836-4849$.

Kincaid, CT, PW Eslinger, RL Aaberg, TB Miley, IC Nelson, DL Strenge, JC Evans, Jr. 2006. Inventory Data Package for Hanford Assessments. PNNL-15829, Pacific Northwest National Laboratory, Richland, Washington. 
Lee MH, MJ Truex, DM Wellman, MD Freshley, D Katzman, VV Vesselinov, ME Denham, AL Bunn, C Eddy-Dilek, JG Morse, KM Thompson, EM Pierce, GS Chamberlain, and KD Gerdes. 2014. "Systems-Based Framework for Remediation Endpoints." In Waste Management Symposia 2014. PNNL-SA-99956, Pacific Northwest National Laboratory, Richland, Washington.

Liger E, L Charlet, and P Van Cappellen. 1999. "Surface catalysis of uranium(VI) reduction by iron(II)." Geochemica et Cosmochimica Acta 63:2939-2955.

Liu C, J Zachara, O Qafoku, J McKinley, S Heald, and Z Wang. 2004. "Dissolution of Uranyl Microprecipitates in Subsurface Sediments at Hanford Site, USA." Geochimica et Cosmochimica Acta 68(22):4519-4537.

Liu C, J Zachara, N Qafoku, and Z Wang. 2008. “Scale-Dependent Desorption of Uranium from Contaminated Subsurface Sediments.” Water Resources Research 44:2454-2461.

McKinley J, J Zachara, C Liu, S Heald, B Prenitzer, and B Kempshall. 2006. "Microscale controls on the fate of contaminant uranium in the vadose zone, Hanford Site, Washington." Geochemica et Cosmochimica Acta 70:1873-1887.

Meier KM. 2014. Deep Vadose Zone Applied Field Research Initiative Quality Assurance Plan. QA-DVZ-AFRI-001, Rev. 1, Pacific Northwest National Laboratory, Richland, Washington.

PAAA (Price-Anderson Amendments Act). Energy Policy Act of 2005. Title VI-Nuclear Matters, Subtitle A-Price-Anderson Act Amendments, Section 601 et. seq. Public Law 109-58, as amended. 42 USC 15801 et seq.

Qafoku NP, CC Ainsworth, JE Szecsody, and OS Qafoku. 2003 "Effect of coupled dissolution and redox reactions on $\mathrm{Cr}(\mathrm{VI})$ aq attenuation during transport in the Hanford sediments under hyperalkaline conditions." Environmental Science and Technology 37:3640-3646.

Qafoku NP, CC Ainsworth, JE Szecsody, and OS Qafoku. 2004. Transport-controlled kinetics of dissolution and precipitation in the sediments under alkaline and saline conditions, Geochemica et Cosmochimica Acta 68(14):2981-2995.

Qafoku NP and JP Icenhower. 2008. Interactions of aqueous U(VI) with soil minerals in slightly alkaline natural systems. Reviews in Environmental Science and Biotechnology 7:355-380.

Serne RJ, BN Bjornstad, HT Schaef, BA Williams, DC Lanigan, DG Horton, RE Clayton, AV Mitroshkov, VL LeGore, MJ O’Hara, CF Brown, KE Parker, IV Kutnyakov, JN Serne, GV Last, SC Smith, CW Lindenmeier, JM Zachara, and DS Burke. 2008. Characterization of Vadose Zone Sediment: Uncontaminated RCRA Borehole Core Samples and Composite Samples. PNNL-13757-1, Rev. 1, Pacific Northwest National Laboratory, Richland, Washington.

Simpson BC, RA Corbin, MJ Anderson, CT Kincaid, and JM Zachara. 2006. Identification and Classification of the Major Uranium Discharges and Unplanned Releases at the Hanford Site Using the Soil Inventory Model (SIM) Rev. 1 Results. NUV-06-21106-ES-001-DOC Rev. 1, Novotec, USA Inc., Cincinnati, Ohio. 
Sumner ME. 2000. "Soil Fertility and Plant Nutrition." Section D in Handbook of Soil Science, CRC Press, Boca Raton, Florida.

Szecsody JE, MJ Truex, L Zhong, MD Williams, and CT Resch. 2010a. Remediation of Uranium in the Hanford Vadose Zone Using Gas-Transported Reactants: Laboratory-Scale Experiments. PNNL-18879, Pacific Northwest National Laboratory, Richland, Washington.

Szecsody, JE, MJ Truex, L Zhong, NP Qafoku, MD Williams, JP McKinley, CT Resch, JL Phillips, D Faurie, and J Bargar. 2010b. Remediation of Uranium in the Hanford Vadose Zone Using Ammonia Gas: FY10 Laboratory-Scale Experiments. PNNL-20004, Pacific Northwest National Laboratory, Richland, Washington.

Szecsody JE, MJ Truex, L Zhong, TC Johnson, NP Qafoku, M.D Williams, JW Greenwood, EL Wallin, JD Bargar, and DK Faurie. 2012. "Geochemical and Geophysical Changes During NH3 Gas Treatment of Vadose Zone Sediments for Uranium Remediation." Vadose Zone Journal 11(4). doi: 10.2136/vzj2011.0158.

Szecsody JE, MJ Truex, NP Qafoku, DM Wellman, T Resch, and L Zhong. 2013. "Influence of acidic and alkaline waste solution properties on uranium migration in subsurface sediments." Journal of Contaminant Hydrology 151:155-175. dx.doi.org/10.1016/j.jconhyd.2013.05.009

Tokunaga T, J Wan, J Pena, S Sutton, and M Newville. 2004. "Hexavalent uranium diffusion into soils from concentrated acidic and alkaline solutions." Environmental Science and Technology 38:3056-3062.

Truex MJ and KC Carroll. 2013. Remedy Evaluation Framework for Inorganic, Non-Volatile Contaminants in the Deep Vadose Zone. PNNL-21815, Pacific Northwest National Laboratory, Richland, Washington.

Um W, Z Wang, J Serne, B Williams, C Brown, C Dodge, and A Francis. 2009. "Uranium phases in contaminated sediments below Hanford's U tank farm." Environmental Science and Technology 43:4280-4286.

Wan JM, JT Larsen, TK Tokunaga, and ZP Zheng. 2004a. "pH neutralization and zonation in alkalinesaline tank waste plumes.” Environmental Science and Technology 38:1321-1329.

Wan JM, TK Tokunaga, JT Larsen, and RJ Serne. 2004b. "Geochemical evolution of highly alkaline and saline tank waste plumes during seepage through vadose zone sediments." Geochemica et Cosmochimica Acta 68:491-502.

Zachara J, C Liu, C Brown, S Kelly, J Christensen, J McKinley, J Davis, J Serne, E Dresel, and W Um. 2007. A Site-Wide Perspective on Uranium Geochemistry at the Hanford Site. PNNL-17031, Pacific Northwest National Laboratory, Richland, Washington.

Zachara J, C Ainsworth, G Brown, J Catalano, J McKinley, O Qafoku, S Smith, J Szecsody, S Traina, and J Warner. 2004. "Chromium speciation and mobility in a high level nuclear waste vadose zone plume." Geochimica et Cosmochimica Acta 68(1):13-30. 
Zhao HT, YJ Deng, JB Harsh, M Flury, and JS Boyle. 2004. Alteration of kaolinite to cancrinite and sodalite by simulated Hanford tank waste and its impact on cesium retention. Clays and Clay Minerals 52:1-13. 


\section{Appendix A}

Sediment Mineralogy Information for the Hanford Central Plateau 



\section{Appendix A}

\section{Sediment Mineralogy Information for the Hanford Central Plateau}

This appendix provides a summary of sediment mineralogy information for the Hanford Central Plateau. This information and associated references could be used as a starting point for the sediment mineralogy element of a site-specific conceptual model at Hanford Central Plateau waste sites.

\section{A.1 General Mineralogy}

In general, the sand and gravel mineralogy of the Hanford formation is similar across the Hanford Central Plateau because of common geologic provenance. Gravel-sized clasts generally consist of $>50 \%$ subangular to subrounded basalt rock fragments (DOE/RL 2002). Sand facies generally contain $50 \%$ basaltic lithic fragments and $50 \%$ granitic fragments, whereas silt is typically dominated by quartz, various feldspars, and micas (biotite and muscovite) (Ginder-Vogel et al. 2005; Tallman et al. 1979; Zachara et al. 2002). The clay fraction of Hanford formation vadose zone sediments is remarkably consistent between different vadose zone samples (Zachara et al. 2002) and is dominated by expansible phyllosilicates (smectite), ferroan chlorite (chlinochlore), and mica (both biotite and muscovite) with serpentine-group minerals (antigorite and lizardite) also being reported (Ginder-Vogel et al. 2005).

Although the relative abundances of individual minerals vary widely, the bulk samples $(<2$-mm size fraction) of these sediments are largely dominated by quartz $\left(\mathrm{SiO}_{2}\right)$, plagioclase feldspar [general formula $(\mathrm{Na}, \mathrm{Ca}) \mathrm{Al}(\mathrm{Al}, \mathrm{Si}) \mathrm{Si}_{2} \mathrm{O}_{8}$ ], and alkali (potassium) feldspar $\left(\mathrm{KAlSi}_{3} \mathrm{O}_{8}\right)$ with quartz usually being the dominant of these three minerals and plagioclase usually being more abundant that alkali feldspar. The bulk sediment samples also generally contain minor amounts of mica, chlorite, amphibole, smectite, and/or detrital calcite $\left(\mathrm{CaCO}_{3}\right.$, calcium carbonate) ${ }^{1}$

Detrital and pedogenic calcite are consistently observed throughout the Hanford formation vadose zone sediments ranging in concentrations from $\sim 1$ to a maximum of $5 \%$ and averaging 1.79 mass $\%$ (Serne et al., 2008g). Pedogenic calcite exists in the form of discrete, but infrequent caliche layers $(\sim 25$ $\mathrm{cm}$ in thickness) that formed beneath surfaces that were exposed for extended inter-flood periods during the Pleistocene. A calcite-indurated paleosol with 35-45\% calcite frequently occurs in the lower Cold Creek Unit $\left(\mathrm{CCU}_{\mathrm{c}}\right)$. The concentration of calcium carbonate within the $\mathrm{CCU}_{\mathrm{c}}$ varies over a wide range, and can be as large as $70 \mathrm{wt} \%$. Other names used to describe these facies have included "caliche" and "calcrete" (Reidel and Chamness 2007).

Zachara et al. (2007) noted that the vadose zone sediments at the Hanford Site invariably contain a magnetic, iron-rich mineral fraction (probably less than 2 mass \%) that contains magnetite ( $\left.\mathrm{Fe}(\mathrm{II}) \mathrm{Fe}_{2}(\mathrm{III}) \mathrm{O}_{4}\right)$, ilmenite $\left(\mathrm{FeTiO}_{3}\right), \mathrm{Fe}(\mathrm{II}) / \mathrm{Fe}(\mathrm{III})$ phyllosilicates, and $\mathrm{Fe}(\mathrm{III})$ oxides (ferrihydrite [nominally $\left.5 \mathrm{Fe}_{2} \mathrm{O}_{3} \cdot 9 \mathrm{H}_{2} \mathrm{O}\right]$ ); and goethite $[\alpha-\mathrm{FeO}(\mathrm{OH})]$ ), based on X-ray diffraction and transmission Mössbauer spectroscopy. For example, see the mineralogical characterization data of Ginder-Vogel et al.

\footnotetext{
${ }^{1}$ Mica, chlorite, amphibole, and smectite are mineral groups that are each characterized by specific structural features and some general ranges in composition.
} 
(2005) for sediment samples from the Integrated Disposal Facility. Zachara et al. (2007) indicated that this potentially reactive iron-bearing mineral fraction has not been well studied and is expected to show considerable variation between and within stratigraphic units.

Hanford formation sediments are, in general, only modestly weathered because of youthful age, whereas the Ringold Formation sediments can be quite weathered and show more hydrous oxide coatings of iron, manganese, and aluminum compared to the young Hanford formation sediments. The Cold Creek Unit shows signs of pedogenesis. All Hanford sediments not affected by Hanford wastes exhibit a soil water $\mathrm{pH}$ near neutrality because of high levels of dissolved bicarbonate in pore water and the frequent presence of calcite.

\section{A.2 Specific Waste-Site Studies}

The clay-size fractions $(<2 \mu \mathrm{m})$ of the sediment samples analyzed for mineralogy in the studies listed below in Table A.1 are dominated by four clay minerals illite \{general formula $\left.\left(\mathrm{K}, \mathrm{H}_{3} \mathrm{O}\right)(\mathrm{Al}, \mathrm{Mg}, \mathrm{Fe})_{2}(\mathrm{Si}, \mathrm{Al})_{4} \mathrm{O}_{10}\left[(\mathrm{OH})_{2}, \mathrm{H}_{2} \mathrm{O}\right]\right\}$, smectite, chlorite, and kaolinite $\left[\mathrm{Al}_{2} \mathrm{Si}_{2} \mathrm{O}_{5}(\mathrm{OH})_{4}\right]$ with minor amounts of quartz, feldspar, and amphibole. The transmission electron microscopy/energydispersive spectroscopy (TEM/EDS) analyses of the clay fractions of sediment samples from the Waste Management Area S-SX reported by Serne et al. (2008d, 2008e, 2008f) indicate that the compositions of chlorites typically ranged from that of magnesium-rich chamosite [general formula $\left(\mathrm{Fe}^{\mathrm{II}}, \mathrm{Mg}, \mathrm{Fe}^{\mathrm{III}}\right)_{5} \mathrm{Al}\left(\mathrm{Si}_{3}, \mathrm{Al}\right) \mathrm{O}_{10}(\mathrm{OH}, \mathrm{O})_{8}$ ] to iron-rich clinochlore [general formula $\left.\left(\mathrm{Mg}, \mathrm{Fe}^{\mathrm{II}}\right)_{5} \mathrm{Al}\left(\mathrm{Si}_{3}, \mathrm{Al}\right) \mathrm{O}_{10}(\mathrm{OH}, \mathrm{O})_{8}\right]$. In addition, the TEM/EDS analyses also identified the presence of iron oxide(s), anatase $\left(\mathrm{TiO}_{2}\right)$, apatite, and sepiolite $\left[\mathrm{Mg}_{4} \mathrm{Si}_{6} \mathrm{O}_{15}(\mathrm{OH})_{2} \bullet 6 \mathrm{H}_{2} \mathrm{O}\right]$ (Serne et al. 2008d, 2008e, 2008f, 2008b). Some of the samples analyzed by TEM/EDS by Serne et al. (2008f) contained platy particles of weathered muscovite $\left[\mathrm{KAl}_{2}\left(\mathrm{Si}_{3} \mathrm{Al}\right) \mathrm{O}_{10}(\mathrm{OH})_{2}\right]$ and, in lesser amounts, weathered biotite $\left[\mathrm{K}\left(\mathrm{Mg}, \mathrm{Fe}^{\mathrm{II}}\right)_{3}\left(\mathrm{Al}, \mathrm{Fe}^{\mathrm{III}}\right) \mathrm{Si}_{3} \mathrm{O}_{10}(\mathrm{OH}, \mathrm{F})_{2}\right]$. 
Table A.1. Summary of mineralogical analyses of vadose zone sediments from 200-West and 200-East single-shell tank waste management areas.

\begin{tabular}{|c|c|c|c|c|}
\hline $\begin{array}{l}\text { Waste } \\
\text { Management } \\
\text { Area }\end{array}$ & Reference & Borehole/Well & $\begin{array}{l}\text { Stratigraphic Units From Which } \\
\text { Samples Used for Mineralogical } \\
\text { Analyses Were Sampled }\end{array}$ & Method of Mineralogical Analysis \\
\hline \multicolumn{5}{|c|}{200 West SST WMAs } \\
\hline S-SX & $\begin{array}{l}\text { Serne et al. } \\
(2008 d)\end{array}$ & $\begin{array}{l}\text { Clean RCRA wells } \\
\text { 299-W22-48 and } \\
\text { 299-W22-50, and four } \\
\text { composite samples }\end{array}$ & $\begin{array}{l}\text { Analyzed composite samples from } \\
\text { Hanford formation and Ringold } \\
\text { Formation } \\
\text { Sediment samples analyzed by XRD and } \\
\text { TEM/EDS from wells 299-W22-48 and } \\
\text { 299-W22-50 from various units of } \\
\text { Hanford formation, Cold Creek Unit, } \\
\text { and Ringold Formation }\end{array}$ & $\begin{array}{l}\text { XRD analysis of bulk sample and of the clay- and } \\
\text { silt-size fractions of selected sediment samples; } \\
\text { TEM and EDS analyses of clay minerals in selected } \\
\text { samples }\end{array}$ \\
\hline $\begin{array}{l}\text { S-SX (near } \\
\text { SX-115) }\end{array}$ & $\begin{array}{l}\text { Serne et al. } \\
(2008 \mathrm{e})\end{array}$ & Well 299-W23-19 & $\begin{array}{l}\text { Sediment samples analyzed by XRD and } \\
\text { TEM/EDS from various units of } \\
\text { Hanford formation and Cold Creek Unit }\end{array}$ & $\begin{array}{l}\text { XRD analysis of bulk sample and clay-size fraction } \\
\text { of selected sediment samples; TEM and EDS } \\
\text { analyses of clay minerals in selected samples }\end{array}$ \\
\hline $\begin{array}{l}\text { S-SX (near } \\
\text { SX-109) }\end{array}$ & $\begin{array}{l}\text { Serne et al. } \\
(2008 f)\end{array}$ & Borehole 41-09-39 & $\begin{array}{l}\text { Sediment samples analyzed by XRD and } \\
\text { TEM/EDS from various units of } \\
\text { Hanford formation }\end{array}$ & $\begin{array}{l}\text { XRD analysis of bulk samples and sand-size } \\
\text { fraction; TEM and EDS analyses of selected clay } \\
\text { samples }\end{array}$ \\
\hline $\begin{array}{l}\text { S-SX (below } \\
\text { SX-108) }\end{array}$ & $\begin{array}{l}\text { Serne et al. } \\
(2008 b)\end{array}$ & $\begin{array}{l}\text { Slant borehole below } \\
\text { SST SX-108 }\end{array}$ & $\begin{array}{l}\text { Sediment samples analyzed by XRD } \\
\text { from various units of Hanford formation } \\
\text { and from the Cold Creek Unit; samples } \\
\text { analyzed by TEM/EDS from various } \\
\text { units of Hanford formation }\end{array}$ & $\begin{array}{l}\text { XRD analysis of bulk samples and clay-size } \\
\text { fraction; TEM and EDS analyses of selected clay } \\
\text { samples }\end{array}$ \\
\hline $\begin{array}{l}\mathrm{T} \text { (borehole } \\
\text { southwest of } \\
\text { tank T-106) }\end{array}$ & $\begin{array}{l}\text { Serne et al. } \\
(2008 \mathrm{~h})\end{array}$ & Borehole C4105 & $\begin{array}{l}\text { Sediment samples analyzed by XRD } \\
\text { from various units of Hanford formation, } \\
\text { Cold Creek Unit, and Ringold Formation }\end{array}$ & $\begin{array}{l}\text { XRD analysis of bulk samples and clay-size } \\
\text { fraction }\end{array}$ \\
\hline
\end{tabular}


Table A.1. (contd)

\begin{tabular}{|c|c|c|c|c|}
\hline $\begin{array}{l}\text { Waste } \\
\text { Management } \\
\text { Area }\end{array}$ & Reference & Borehole/Well & $\begin{array}{l}\text { Stratigraphic Units From Which } \\
\text { Samples Used for Mineralogical } \\
\text { Analyses Were Sampled }\end{array}$ & Method of Mineralogical Analysis \\
\hline \multicolumn{5}{|c|}{200 SST East WMAs } \\
\hline $\begin{array}{l}\text { A-AX } \\
\text { (southwest/ } \\
\text { south of } \\
\text { A-AX) }\end{array}$ & $\begin{array}{l}\text { Brown et al. } \\
(2005)\end{array}$ & $\begin{array}{l}\text { RCRA wells } \\
\text { 299-E25-46 and } \\
\text { 299-E24-19 }\end{array}$ & $\begin{array}{l}\text { Sediment core samples analyzed by } \\
\text { XRD from Hanford formation }\end{array}$ & $\begin{array}{l}\text { XRD analysis of bulk samples of sediment core and } \\
\text { sidewall core from both wells }\end{array}$ \\
\hline $\begin{array}{l}\text { B-BX-BY } \\
\text { (northeast of } \\
\text { tank BX-102) }\end{array}$ & $\begin{array}{l}\text { Serne et al. } \\
(2008 \mathrm{c})\end{array}$ & Well 299-E33-45 & $\begin{array}{l}\text { Sediment samples analyzed by XRD and } \\
\text { TEM/EDS from various units of } \\
\text { Hanford formation and Cold Creek Unit }\end{array}$ & $\begin{array}{l}\text { XRD analysis of bulk samples and clay-size } \\
\text { fraction; TEM and EDS analyses of TEM) } \\
\text { characterization of selected clay samples }\end{array}$ \\
\hline $\begin{array}{l}\text { B-BX-BY } \\
\text { (near tank } \\
\text { B-110) }\end{array}$ & $\begin{array}{l}\text { Serne et al. } \\
\text { (2008a) }\end{array}$ & Well 299-E33-46 & $\begin{array}{l}\text { Sediment samples analyzed by XRD } \\
\text { from various units of Hanford formation } \\
\text { and Cold Creek Unit }\end{array}$ & $\begin{array}{l}\text { XRD analysis of bulk samples and clay-size } \\
\text { fractions }\end{array}$ \\
\hline $\begin{array}{l}\text { B-BX-BY } \\
\text { (southeast of } \\
\text { B Tank Farm) }\end{array}$ & $\begin{array}{l}\text { Lindenmeier et al. } \\
\text { (2003) }\end{array}$ & $\begin{array}{l}\text { RCRA well } \\
\text { 299-E33-338 }\end{array}$ & $\begin{array}{l}\text { Sediment samples analyzed by XRD } \\
\text { from various units of Hanford formation } \\
\text { and Cold Creek Unit }\end{array}$ & Analysis by XRD of bulk samples of sediment core \\
\hline $\begin{array}{ll}\text { EDS } & =\text { ener } \\
\text { NA } & =\text { not } \\
\text { RCRA } & =\text { Resc } \\
\text { SEM } & =\text { scan } \\
\text { TEM } & =\text { tran } \\
\text { XRD } & =\text { X-ra }\end{array}$ & $\begin{array}{l}\text { y-dispersive spectro } \\
\text { pplicable. } \\
\text { urce Conservation a } \\
\text { ing electron micros } \\
\text { mission electron mic } \\
\text { y diffraction. }\end{array}$ & $\begin{array}{l}\text { netry. } \\
\text { d Recovery Act of } 1976 . \\
\text { opy. } \\
\text { oscopy. }\end{array}$ & & \\
\hline
\end{tabular}


The S-SX sediment samples and the types of mineralogical analyses completed are summarized in Table A.2. An extensive part of the mineralogical characterization studies described in the references in Table A.2 is summarized by McKinley et al. (2001). Key results from the mineralogical studies by McKinley et al. (2001) and Zachara et al. $(2002,2004)$ are briefly summarized below. Similar mineralogical information is given by Liu et al. (2003) and McKinley et al. (2004).

Characterization of the sediment samples studied by Zachara et al. (2002, p 193) show the mineralogy of the size fractions greater than $2 \mu \mathrm{m}$ was dominated by quartz with lesser amounts of plagioclase and potassium feldspars, micas, chlorite, vermiculite $\left[\left(\mathrm{Mg}, \mathrm{Fe}^{\mathrm{II}}, \mathrm{Al}\right)_{3}(\mathrm{Al}, \mathrm{Si})_{4} \mathrm{O}_{10}(\mathrm{OH})_{2} \bullet 4 \mathrm{H}_{2} \mathrm{O}\right]$, and smectite. Anorthite $\left(\mathrm{CaAl}_{2} \mathrm{Si}_{2} \mathrm{O}_{8}\right)$ was the dominant feldspar mineral. The clay-size fraction $(<2 \mu \mathrm{m})$ contained smectite, chlorite (clinochlore), and mica. Based on XRD analysis of a mica concentrate hand-picked from the sand fraction $(0.5-2.0 \mathrm{~mm})$, Zachara et al. (2002) identified the micas muscovite, biotite, and vermiculitized biotite. Zachara et al. (2002) observed a cream-colored encrustation on the basal surfaces of biotite and vermiculitized biotite, which they identified as feldspar by XRD analysis. These analyses showed the basal surfaces of some of the biotite to be highly weathered to vermiculite, whereas the internal surfaces of the biotite were unaltered (Zachara et al. 2002). Bright red and dark brown colors of the vermiculite and biotite grains, respectively, determined by optical microscopy were consistent with oxidation of octahedrally coordinated iron during weathering (Zachara et al. 2002).

The mineralogy determined by McKinley et al. (2001) on their S-SX sediment samples was essentially identical to that described by Zachara et al. (2002). Quartz, plagioclase feldspar, and micas (biotite, muscovite, and vermiculitized biotite) were identified in all size fractions, with kaolinite, quartz, plagioclase, smectite, and micas being the principal minerals in the clay-size fraction (McKinley et al. 2001). McKinley et al. (2001, p. 3433) used digital phosphor-plate images to identify the mineral particles in their sediment samples responsible for sorbing ${ }^{137} \mathrm{Cs}$. Their autoradiograph analyses indicated that the cesium-bearing particles were individual grains of mica or agglomerates of smectite, mica, quartz, and plagioclase.

Mineralogical characterization by Zachara et al. (2004) shows definite evidence that dissolution and precipitation reactions had occurred in sediment samples from the SX-108 slant borehole as a result of contact with tank liquid wastes. Although the surfaces of mica grains in uncontaminated Hanford sediments show no alteration, the scanning electron microscopy (SEM) analyses of muscovite and biotite grains in sediment samples from the SX-108 slant borehole (samples 3A and 7A) indicated the grains were highly coated with poorly crystalline sodium aluminosilicates. Zachara et al. (2004) noted that, based on the SEM analyses, the degree of alteration of the sediments decreased with depth and distance from the tank.

X-ray adsorption near edge structure spectroscopy (XANES) analyses of chromium-rich sediment samples from the SX-108 slant borehole indicated the presence of both $\mathrm{Cr}(\mathrm{VI})$ and $\mathrm{Cr}(\mathrm{III})$. Zachara et al. (2004) found that the largest $\mathrm{Cr}(\mathrm{III})$ concentration [smallest $\mathrm{Cr}(\mathrm{VI})$ ] was observed in sample 7A, which had the largest extent of mineral alteration of the samples analyzed by XANES, whereas the highest $\mathrm{Cr}(\mathrm{VI})$ concentrations were in the samples deeper in the core where mineral alteration was minimal. Zachara et al. (2004) also speculated that the most altered sediment samples - 3A and 7A-should also contain secondary zeolites that formed from reaction with the liquid tank wastes. Zachara et al. (2004) identified grains of quartz that had sodium aluminosilicate precipitates on their surfaces. Because these 
surface coatings did not exist on uncontaminated sediments, Zachara et al. (2004) assumed these surface precipitates were zeolites that formed from reaction with the waste liquids.

Table A.2. Summary of Mineralogical Analyses of Vadose Zone Sediments from Waste Management Area S-SX

\begin{tabular}{|c|c|c|c|}
\hline $\begin{array}{c}\text { S-SX } \\
\text { Borehole/Well }\end{array}$ & Reference $^{(\mathrm{a})}$ & Sample Numbers ${ }^{(b)}$ & Method of Mineralogical Analysis \\
\hline $\begin{array}{l}\text { Borehole 41-09- } \\
39\end{array}$ & $\begin{array}{l}\text { McKinley et al. } \\
(2001)\end{array}$ & $\begin{array}{l}2 \mathrm{C} / 2 \mathrm{D}, 2 \mathrm{~A} / 2 \mathrm{~B}, 3 \mathrm{~A} / 3 \mathrm{~B} \\
12 \mathrm{~A} / 12 \mathrm{~B}\end{array}$ & autoradiography, optical microscopy, XRD \\
\hline $\begin{array}{l}\text { RCRA } \\
\text { monitoring wells }\end{array}$ & $\begin{array}{l}\text { Zachara et al. } \\
(2002)\end{array}$ & $\begin{array}{l}\text { Not specified; sample } \\
\text { from Hanford } \\
\text { formation; used a } \\
\text { subsample of the } \\
\text { composite sediment } \\
\text { (“Above B") }\end{array}$ & optical microscopy, XRD \\
\hline $\begin{array}{l}\text { SX-108 slant } \\
\text { borehole and } \\
\text { borehole } \\
41-09-39\end{array}$ & Liu et al. (2003) & $\begin{array}{l}\text { SX-108 slant ( } 3 A \text { and } \\
7 A) \text { and } 41-09-39 \\
(7 A B C \text { and } 9 A B C)\end{array}$ & SEM, XMP \\
\hline $\begin{array}{l}\text { Borehole not } \\
\text { specified }\end{array}$ & $\begin{array}{l}\text { McKinley et al. } \\
(2004)\end{array}$ & Not specified. & EMP, SEM/EDS, TEM, XMP \\
\hline $\begin{array}{l}\text { SX-108 slant } \\
\text { borehole and } \\
\text { borehole } \\
41-09-39\end{array}$ & $\begin{array}{l}\text { Zachara et al. } \\
(2004)\end{array}$ & $\begin{array}{l}\text { SX-108 slant (3A, 6A, } \\
7 \mathrm{~A}, 8 \mathrm{~A}, 9 \mathrm{~A}, 13 \mathrm{~A}, 14 \mathrm{~A}) \\
\text { and } 41-09-39 \text { (6AB and } \\
7 \mathrm{ABC})\end{array}$ & SEM/EDS, XANES, XRD, SXRF \\
\hline \multicolumn{4}{|c|}{$\begin{array}{l}\text { (a) A considerable part of the mineralogical characterization studies reported in the references above is summarized by } \\
\text { McKinley et al. ( } 2001 \text {; S-SX Field Investigation Report [FIR]). } \\
\text { (b) It is assumed that the sample numbers listed above correspond to those given in Serne et al. (2008b, PNNL-13757-4) } \\
\text { and Serne et al. (2008f, PNNL-13757-3) for sediment samples from SX-108 slant borehole and borehole 41-09-39, } \\
\text { respectively. It is also assumed that samples numbers with combined letters listed in the studies cited above } \\
\text { represented composite samples. }\end{array}$} \\
\hline $\begin{array}{ll}\text { EDS }=\text { energy-dis } \\
\text { EMP } & =\text { electro } \\
\text { SEM } & =\text { scann } \\
\text { SXRF } & =\text { synch } \\
\text { TEM } & =\text { transn } \\
\text { XANES } & =\text { X-ray } \\
\text { XMP } & =\text { synch } \\
\text { XRD } & =\text { X-ray }\end{array}$ & $\begin{array}{l}\text { rsive spectrometry } \\
\text { microprobe. } \\
\text { electron microsc } \\
\text { tron-based energy } \\
\text { sion electron mic } \\
\text { dsorption near edg } \\
\text { tron-based X-ray } \\
\text { ffraction. }\end{array}$ & $\begin{array}{l}\text { ersive X-ray fluorescence } \\
\text { py. } \\
\text { ucture spectroscopy. } \\
\text { oprobe. }\end{array}$ & \\
\hline
\end{tabular}

Mineralogical analyses have been conducted to determine the geochemical reactions controlling the sorption and speciation of ${ }^{90} \mathrm{Sr}$ (McKinley et al. 2007) in contaminated sediment samples from B 110 borehole 299-E33-46 and uranium in contaminated sediment samples from BX 102 borehole 299-E33-45 (Catalano et al. 2004; Liu et al. 2004; Wang et al. 2005; Liu et al. 2006; McKinley et al. 2006). The B and $\mathrm{BX}$ sediment samples that were analyzed and the types of mineralogical analyses completed by these studies are summarized in Table A.3. These studies focused on establishing the reaction mechanisms controlling the geochemical behavior of specific contaminants in these sediments. In general the same types and relative amounts of minerals as discussed above for vadose sediments from the SX Tank Farm are present in the vadose zone sediments from the B and BX Tank Farms. For the contaminated sediments directly below the tanks, the B and BX Tank Farm sediments show less alkaline attack that 
leads to zeolites formation. In fact no significant alkaline attack has been observed beneath the B and BX Tank Farms in the two boreholes available, potentially due to a combination of the tank fluids being less concentrated and caustic and the location of the boreholes being more distant from the tanks themselves than for the studies at the SX Tank Farm. 
Table A.3. Summary of Mineralogical Analyses of Vadose Zone Sediments from Waste Management Area B-BX-BY

\begin{tabular}{|c|c|c|c|}
\hline $\begin{array}{c}\text { B-BX-BY } \\
\text { Borehole/Well }\end{array}$ & Reference $^{(a)}$ & Sample Numbers ${ }^{(\mathrm{b})}$ & Method of Mineralogical Analysis \\
\hline $\begin{array}{l}\text { B-110 Borehole } \\
\text { 299-E33-46 }\end{array}$ & McKinley et al. (2007) & $\begin{array}{l}\text { Split-spoon liner samples; 20b, 21a, 36a, 38a, 84, 105c, } \\
110 b, 113\end{array}$ & SEM/EDS, digital micro-autoradiography \\
\hline $\begin{array}{l}\text { BX-102 Borehole } \\
\text { 299-E33-45 }\end{array}$ & Catalano et al. (2004) & $33 \mathrm{AB}, 53 \mathrm{AB}, 61 \mathrm{AB}, 67 \mathrm{AB}$ & EXAFS, $\mu$ XRD, $\mu$ SXRF, XAFS, XANES \\
\hline $\begin{array}{l}\text { BX-102 Borehole } \\
\text { 299-E33-45 }\end{array}$ & Liu et al. (2004) & I53, I61, I67 & EMP, SEM, XMP \\
\hline $\begin{array}{l}\text { BX-102 Borehole } \\
\text { 299-E33-45 }\end{array}$ & Wang et al. (2005) & $53 \mathrm{~A}, 61 \mathrm{~A}, 61 \mathrm{AB}, 67 \mathrm{AB}$ & TRLFS, XRD \\
\hline $\begin{array}{l}\text { BX-102 Borehole } \\
\text { 299-E33-45 }\end{array}$ & Liu et al. (2006) & None given & NMR-PGSE, SEM, XRD \\
\hline $\begin{array}{l}\text { BX-102 Borehole } \\
\text { 299-E33-45 }\end{array}$ & McKinley et al. (2006) & Split-spoon liner samples & EMP, SEM/EDS, TEM, XRM \\
\hline 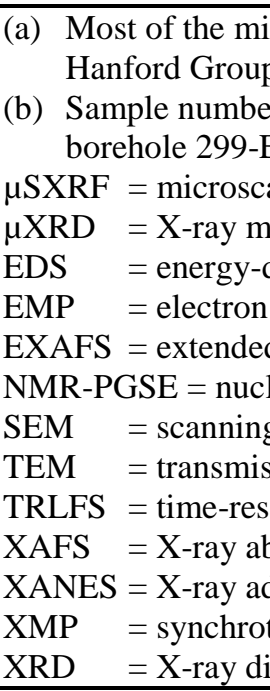 & $\begin{array}{l}\text { epalogical characterizatio } \\
\text { eport (2002). } \\
\text { listed are assumed to co } \\
\text { 3-45, respectively. Sam } \\
\text { ning X-ray fluorescence } \\
\text { rodiffraction. } \\
\text { persive spectrometry. } \\
\text { iicroprobe. } \\
\text { X-ray absorption fine str } \\
\text { ar magnetic resonance pu } \\
\text { lectron microscopy. } \\
\text { on electron microscopy. } \\
\text { ved spectroscopy laser fl } \\
\text { orption fine structure spe } \\
\text { orption near edge structu } \\
\text { on-based X-ray micropro } \\
\text { raction. }\end{array}$ & $\begin{array}{l}\text { spond to those in Serne et al. (2008a, c) for sediment san } \\
\text { numbers with a combined letter listed in the cited studie } \\
\text { ure spectroscopy. } \\
\text { gradient spin echo technique. } \\
\text { rescence spectroscopy. } \\
\text { oscopy. } \\
\text { spectroscopy. }\end{array}$ & $\begin{array}{l}\text { from B-110 borehole 299-E33-46 and BX-102 } \\
\text { also assumed to represent composite samples. }\end{array}$ \\
\hline
\end{tabular}




\section{A.3 References}

Brown CF, RJ Serne, HT Schaef, BA Williams, MM Valenta, VL LeGore, MJ Lindberg, KN Geiszler, SR Baum, IV Kutnyakov, TS Vickerman, and RE Clayton. 2005. Investigation of Accelerated Casing Corrosion in Two Wells at Waste Management Area A-AX. PNNL-15141, Pacific Northwest National Laboratory, Richland, Washington.

Catalano JG, SM Heald, JM Zachara, and GE Brown Jr. 2004. "Spectroscopic and Diffraction Study of Uranium Speciation in Contaminated Vadose Zone Sediments from the Hanford Site, Washington State." Environmental Science \& Technology 38(10):2822-2828.

CH2M Hill Hanford Group. 2002. Field Investigation Report for Waste Management Area B-BX-BY. RPP-10098, prepared for the U.S. Department of Energy, Office of River Protection, by CH2M HILL Hanford Group, Inc., Richland, Washington.

DOE/RL (U.S. Department of Energy Richland Operations Office). 2002. Standardized Stratigraphic Nomenclature for Post-Ringold Formation Sediments within the Central Pasco Basin. DOE/RL-2002-39, Rev. 0, Richland, Washington.

Ginder-Vogel M, T Borch, MA Mayes, PM Jardine, and S Fendorf. 2005. "Chromate Reduction and Retention Processes within Arid Subsurface Environments." Environmental Science \& Technology 39(20):7833-7839.

Lindenmeier CW, RJ Serne, BN Bjornstad, GW Gee, HT Schaef, DC Lanigan, MJ Lindberg, RE Clayton, VL LeGore, IV Kutnyakov, SR Baum, KN Geiszler, CF Brown, MM Valenta, TS Vickerman, and LJ Royack. 2003. Characterization of Vadose Zone Sediment: RCRA Borehole 299-E33-338 Located Near the B-BX-BY Waste Management Area. PNNL-14121, Pacific Northwest National Laboratory, Richland, Washington.

Liu CX, JM Zachara, SC Smith, JP McKinley, and CC Ainsworth. 2003. "Desorption Kinetics of Radiocesium from Subsurface Sediments at Hanford Site, USA." Geochimica et Cosmochimica Acta 67(16):2893-2912.

Liu CX, JM Zachara, and SC Smith. 2004. "A Cation Exchange Model to Describe Cs+ Sorption at High Ionic Strength in Subsurface Sediments at Hanford Site, USA." Journal of Contamination Hydrology 68(3-4):217-238.

Liu CX, JM Zachara, W Yantasee, PD Majors, and JP McKinley. 2006. "Microscopic Reactive Diffusion of Uranium in the Contaminated Sediments at Hanford, United States." Water Resources Research 42(12): Art. No. W12420.

McKinley JP, CJ Zeissler, JM Zachara, RJ Serne, RM Lindstrom, HT Schaef, and RD Orr. 2001a. "Distribution and Retention of Cs-137 in Sediments at the Hanford Site, Washington." Environmental Science \& Technology 35(17):3433-3441. 
McKinley JP, JM Zachara PL Gassman, CC Ainsworth, B Arey, S McKinley S., HT Schaef, SC Smith, J Kimberling, DL Bish, SJ Chipera, and P Snow. 2001b. "S-SX Site Mineralogy." In Appendix D: Digest of $S \& T$ Program Evaluations, RPP-7884, Rev. 0, AJ Knepp (ed.), pp. D10-D35. CH2M HILL Hanford Group Inc., Richland, Washington.

McKinley JP, JM Zachara, SM Heald, A Dohnalkova, MG Newville, and SR Sutton. 2004. "Microscale Distribution of Cesium Sorbed to Biotite and Muscovite." Environmental Science \& Technology 38(4):1017-1023.

McKinley JP, JM Zachara, CX Liu, SC Heald, BI Prenitzer, and BW Kempshall. 2006. "Microscale Controls on the Fate of Contaminant Uranium in the Vadose Zone, Hanford Site, Washington." Geochimica et Cosmochimica Acta 70(8):1873-1887.

McKinley JP, JM Zachara, SC Smith, and C Liu. 2007. “Cation Exchange Reactions Controlling Desorption of $90 \mathrm{Sr} 2+$ from Coarse-Grained Contaminated Sediments from the Hanford Formation, Washington." Geochimica et Cosmochimica Acta 71(2):305-325.

Reidel SP and MA Chamness. 2007. Geology Data Package for the Single-Shell Tank Waste Management Areas at the Hanford Site. PNNL-15955, Pacific Northwest National Laboratory, Richland, Washington.

Serne RJ, BN Bjornstad, GW Gee, HT Schaef, DC Lanigan, RG McCain, CW Lindenmeier, RD Orr, VL LeGore, RE Clayton, JW Lindberg, IV Kutnyakov, SR Baum, KN Geiszler, MM Valenta, TS Vickerman, and LJ Royack. 2008a. Characterization of Vadose Zone Sediment: Borehole 299-E33-46 Near B-110 in the B-BX-BY Waste Management Area. PNNL-14119, Rev. 1, Pacific Northwest National Laboratory, Richland, Washington.

Serne RJ, GV Last, HT Schaef, DC Lanigan, CW Lindenmeier, CC Ainsworth, RE Clayton, VL LeGore, MJ O'Hara, CF Brown, RD Orr, IV Kutnyakov, TC Wilson, KB Wagnon, BA Williams, and DB Burke. 2008b. Characterization of Vadose Zone Sediment: Slant Borehole SX-108 in the S-SX Waste Management Area. PNNL-13757-4, Rev.1, Pacific Northwest National Laboratory, Richland, Washington.

Serne RJ, GV Last, GW Gee, HT Schaef, DC Lanigan, CW Lindenmeier, MJ Lindberg, RE Clayton, VL LeGore, RD Orr, IV Kutnyakov, SR Baum, KN Geiszler, CF Brown, MM Valenta, and TS Vickerman. 2008c. Characterization of Vadose Zone Sediment: Borehole 299-E33-45 Near BX-102 in the B-BX-BY Waste Management Area. PNNL-14083, Rev. 1, Pacific Northwest National Laboratory, Richland, Washington.

Serne RJ, BN Bjornstad, HT Schaef, BA Williams, DC Lanigan, DG Horton, RE Clayton, AV Mitroshkov, VL LeGore, MJ O’Hara, CF Brown, KE Parker, IV Kutnyakov, JN Serne, GV Last, SC Smith, CW Lindenmeier, JM Zachara, and DS Burke. 2008d. Characterization of Vadose Zone Sediment: Uncontaminated RCRA Borehole Core Samples and Composite Samples. PNNL-13757-1, Rev. 1, Pacific Northwest National Laboratory, Richland, Washington.

Serne RJ, HT Schaef, BN Bjornstad, DC Lanigan, GW Gee, CW Lindenmeier, RE Clayton, VL LeGore, RD Orr, MJ O'Hara, CF Brown, GV Last, IV Kutnyakov, DS Burke, TC Wilson, and BA Williams. 
2008e. Characterization of Vadose Zone Sediment: Borehole 299-W23-19 [SX-115] in the S-SX Waste Management Area. PNNL-13757-2, Rev. 1, Pacific Northwest National Laboratory Richland, Washington.

Serne RJ, GV Last, GW Gee, HT Schaef, DC Lanigan, CW Lindenmeier, RE Clayton, VL LeGore, RD Orr, MJ O’Hara, CF Brown, DS Burke, AT Owen, IV Kutnyakov, TC Wilson, KB Wagnon, BA Williams, and DS Burke. 2008f. Characterization of Vadose Zone Sediment: Borehole 41-09-39 in the S-SX Waste Management Area. PNNL-13757-3, Rev. 1, Pacific Northwest National Laboratory, Richland, Washington.

Serne RJ, BN Bjornstad, DG Horton, DC Lanigan, CW Lindenmeier, MJ Lindberg, RE Clayton, VL LeGore, RD Orr, IV Kutnyakov, SR Baum, KN Geiszler, MM Valenta, and TS Vickerman. 2008g. Characterization of Vadose Zone Sediments Below the TX Tank Farm: Probe Holes C3830, C3831, C3832 and 299-W10-27. PNNL-14594, Rev. 1, Pacific Northwest National Laboratory, Richland, Washington.

Serne RJ, BN Bjornstad, DG Horton, DC Lanigan, CW Lindenmeier, MJ Lindberg, RE Clayton, VL LeGore, KN Geiszler, SR Baum, MM Valenta, IV Kutnyakov, TS Vickerman, RD Orr, and CF Brown. 2008h. Characterization of Vadose Zone Sediments Below the T Tank Farm: Boreholes C4104, C4105, 299-W10-196 and RCRA Borehole 299-W11-39. PNNL-14849, Rev. 1, Pacific Northwest National Laboratory, Richland, Washington.

Wang ZM, JM Zachara, PL Gassman, CX Liu, O Qafoku, W Yantasee, and JG Catalan. 2005. "Fluorescence Spectroscopy of U(VI)-Silicates and U(VI)-Contaminated Hanford Sediment." Geochimica et Cosmochimica Acta 69(6):1391-1403.

Zachara JM, SC Smith, CX Liu, JP McKinley, RJ Serne, and PL Gassman. 2002. "Sorption of Cs+ to Micaceous Subsurface Sediments from the Hanford Site, USA." Geochimica et Cosmochimica Acta 66(2):193-211.

Zachara JM, CC Ainsworth, GE Brown Jr., JG Catalano, JP McKinley, O Qafoku, SC Smith, JE Szecsody, SJ Traina, and JA Warner. 2004. "Chromium Speciation and Mobility in a High Level Nuclear Waste Vadose Zone Plume.” Geochimica et Cosmochimica Acta 68(1):13-30.

Zachara JM, RJ Serne, MD Freshley, FM Mann, FJ Anderson, MI Wood, TE Jones, and DA Myers. 2007. "Geochemical Processes Controlling Migration of High Level Wastes in Hanford's Vadose Zone." Vadose Zone Journal 6(4):985-1003. 

PNNL-23666

RPT-DVZ-AFRI-024

\section{Distribution}

No. of

Copies

\# U.S. Department of Energy Richland Operations Office

Hardcopies:

Briant Charboneau

John Morse
No. of

Copies

Pacific Northwest National

Laboratory

MJ Truex

JE Szecsody

N Qafoku

JR Serne

DM Wellman
(PDF)

(PDF)

(PDF)

(PDF)

(PDF)

Distr.1 




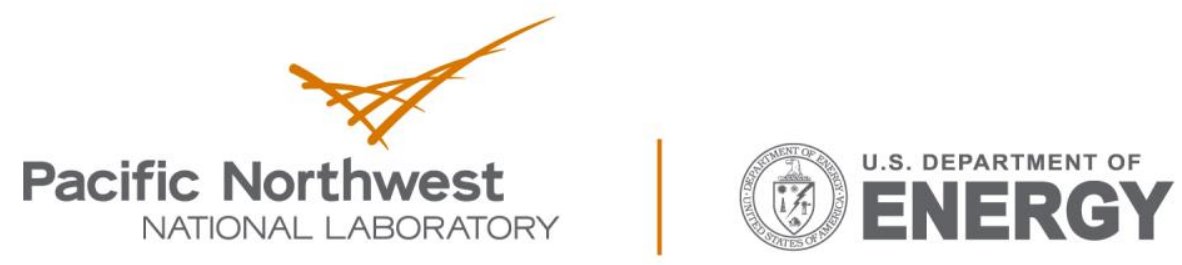

Proudly Operated by Battelle Since 1965

902 Battelle Boulevard

P.O. Box 999

Richland, WA 99352

1-888-375-PNNL (7665)

www.pnnl.gov 